\title{
Mine Productivity Issues: A Case Study of Mopani Mindola Subvertical Mine, Zambia
}

\author{
Jairo Ndhlovu ${ }^{1}$ \\ Peter R K Chileshe ${ }^{2}$ \\ ${ }^{1,2}$ Copperbelt University \\ ${ }^{1}$ Mopani Copper Mines plc - Kitwe Mine Site
}

\begin{abstract}
Global mine productivity issues are of high importance in mining industry and thus, every single effort must be put in place at every mining stage if continuity flow of ore and profitability is to be achieved. Globally mine productivity issues cause production hitches as shown by failure in meeting production targets in the mines. The major global mine productivity problems that lead to instability in sustainable ore production are drilling, stoping, ventilation systems, blasting, rock fragmentation, dilution, haul road /rail track maintenance, ore handling and equipment maintenance. The objective of the paper was to review Mindola subvertical mine (MSV) productivity issues that lead to ore production shortfalls, and to compare with global standards. The study was based on the data collected at MSV mine site through underground field visits, verbal deliberations with personnel in different departments of the mine who shaded more light on the productivity and production activities based on the historical records and experiences. Furthermore, other information pertaining to the same came from: Journals, Mining magazines, Internet, Text books, and Stake holders. Data was then outlined, interpreted and analysed.
\end{abstract}

The study concluded that in order to improve MSV productivity and production, firstly, supervision of operations and maintenance needs to be well optimised, secondly, technology innovations and enhancement are vital and, thirdly, efficient implementation of strategic and tactical plans is necessary.

Key words: 1 Management 2.Supervision 3.Sustainability 4.Productivity.5. Production

\section{INTRODUCTION}

The purpose of this paper was to review global mine productivity issues at MSV mine of relevance to sustainable underground ore production and to compare with global standards. The paper presents qualitative and quantitative literature regarding the effect in mine productivity growth of three important factors, which form the mine productivity conceptual framework: technical, operations and maintenance (Figure1).

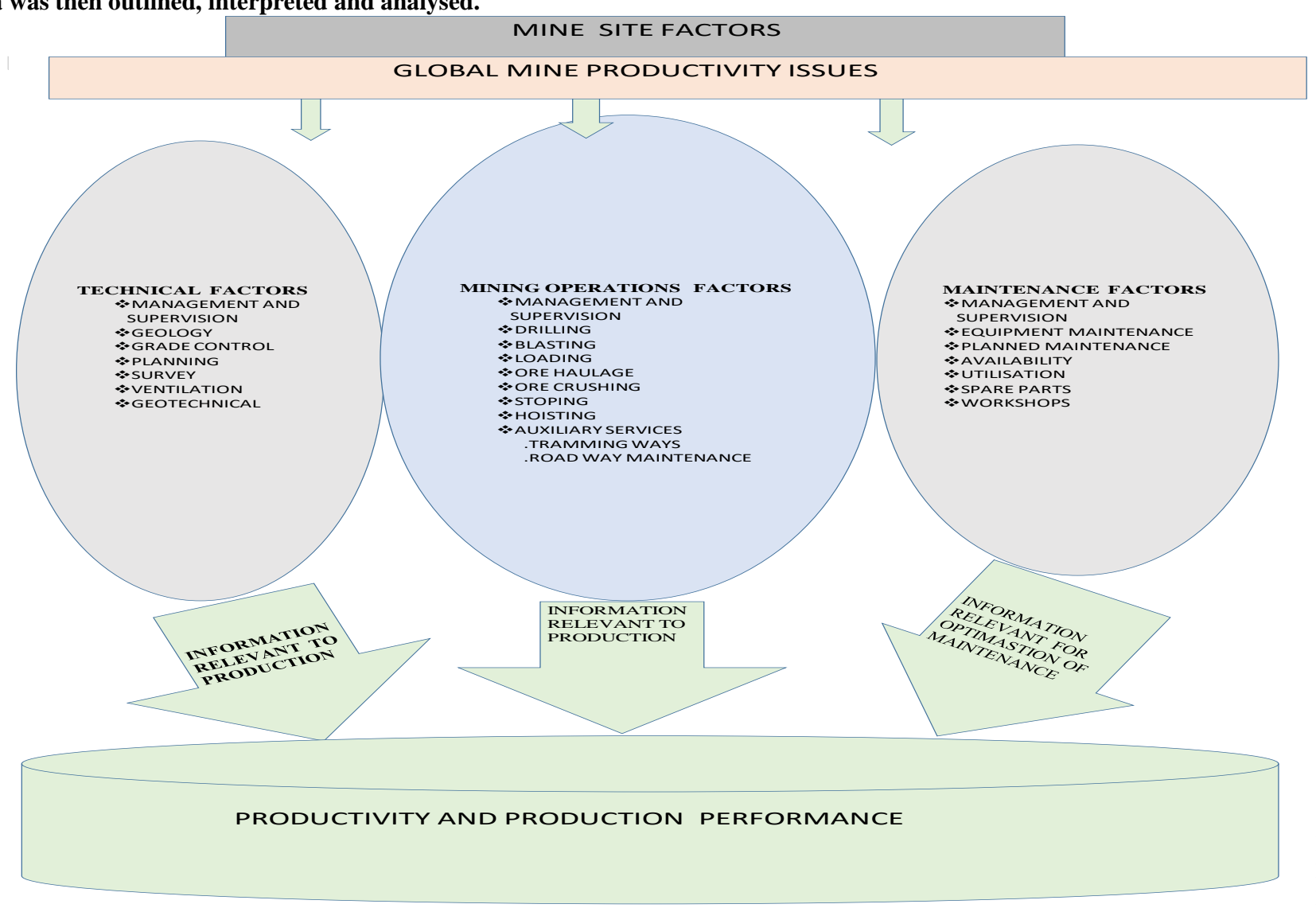

Figure1: Conceptual frame work of global mine productivity parameters (after Ndhlovu and Chileshe 2020) 
Generally, the conceptual framework in this study develops a structure that addresses the research problem and provides insights into productivity and production. From Figure 1, it is seen that at MSV, technical strategy maintenance policy is strongly tied to production policy and site conditions. Hence, determination of an optimum sustainable mine productivity model needs to account for the effects of all three.

\subsection{THEORETICAL FRAMEWORK}

In the paper mine productivity is a measure of performance or output. It is a degree of how effectively the mining business targets of mining companies are being met. The core factors influencing productivity are training, skill of the workforce, quality of supervision, asset in production, technology, equipment, service facilities and overall level of education. In underground mining, productivity entails the state of being able to produce and enhance ore and through puts. Production is the process of transforming any kind of inputs in all mining unit processes to outputs either tangible or intangible.

In the context of mining, drilling is a cutting process that uses a drill bit to make a hole of circular cross-section in into rock mass. The drilling rate of penetration in the rock mass is expressed in metres per hour or per shift. Blasting is a process of breaking a solid rock to fragments by using an explosive, to facilitate easy management of material. Conventional blasting processes include (a) drilling holes, (b) placing a charge and detonator in each hole, (c) detonating the charge, and (d) clearing away the broken material. Upon ignition, the chemical energy in the explosive is liberated, and the compact explosive turn out to be transformed into a glowing gas with an enormous pressure and temperature (Wikipedia, (2020).

The powder factor is a connection between how much rock is broken and how much explosive is used to break the rock and it is expressed as a quantity of rock broken by a unit weight of explosives. The cycle time in underground mining productivity is broken up into loading time, haul to tip time [loaded], dumping time [queuing], spotting [manoeuvring] time at dumping, tipping time, haul to draw point [empty] time, waiting time[queuing] time, spotting time at loading and the same process starts again repeatedly. These are alternatively broken up into loading and haulage cycle times. For maintenance, availability, utilisation and reliability of equipment and machines are the main productivity drives.

\subsection{METHODOLOGY}

The paper is based on the data collected at MSV mine site, outlines the data interpretation and analysis. It took into consideration production essentials matching with the productivity of each unit process such as drilling, blasting, loading and hauling. The paper further looks at the evaluation of mine productivity issues pertaining to production at MSV so as to provide an optimal sustainable ore for smooth planned production targets and improving on ore delivery from the mine site to processing plant. In the paper, data on global mine productivity standards was done through research work of all relevant information pertaining to the study. These included literature on various mine special reports on drilling, charging, blasting, loading, trackless mobile mining machines $\left(\mathrm{TM}^{3}\right)$ and ore handling as well as maintenance of equipment and machines. Furthermore, other information relating to the same came from journals, mining magazines, internet and textbooks. In order to achieve the objective of the study, the literature review on global mine productivity issues on sustainable ore productivity at MSV was categorised into three elements (Figure 1), that is, technical, operations and maintenance, and compare with MSV mine.

\subsection{REVIEW FINDINGS}

Intensive investigations were carried out to assess MSV production failure root causes. Data was compiled from walkover survey, regular visit to underground working area and verbal investigation with; technical, operations and engineering personnel. The comparisons and observations were focused on but not limited to:

\subsection{TECHNICAL FACTORS IN MINE PRODUCTIVITY}

Mine technical section play an essential role in generating feasible production plans that are in line with the requirements of the operations, for profitability and productivity. The technical group disciplines include geology, mine planning and design, geotechnical engineering, survey and ventilation. Mindola subvertical mine, technical strategies for control of input variance and technical decision-making behaviour, has a great influence on mine productivity and production. Generally, the core planned management services offered globally by technical group disciplines in underground mine productivity in comparisons with MSV are similar. (Whittle, 2018).

\subsubsection{Management and supervision}

In the study, MSV mine productivity issues arise as a result of unbalanced supervision elements in technical, operations and maintenance activities. Management strategic and supervision decision making affects the productivity and production at the mine. This is the first of three factors in underground mine productivity and production. The role of the technical management function is to provide technical expertise and overall management of the technical services in accordance with operational need. The challenge is to make technical complexity into a financial model usually designed to produce only one or two key indicators, e.g. net present value (NPV) or internal rate of return (IRR). The mine site objectives of this function are to plan, implement, and maintain a stable technical supervision to support the business processes of the mine which is still reliable on adapting to efficient new supervisory technology.

While globally, the supervisory and motivation of labour force encompasses training and deploying appropriate personnel to learn latest software and operate the technology required to deliver and support mine operations. Furthermore, global mine technical management and supervision rapidly evaluates decisions at different stages of underground projects based on limited and uncertain data. (MacEwan, 2020). 


\subsubsection{Mine planning}

In the study, mine planning is the progression of thinking about the activities required to achieve an anticipated goal. It is the first and prime action to achieve desired results in sustainable ore productivity and production. It involves the establishment and upkeep of a plan, such as a budget or three year plan. At this juncture, the planning function formulates one or more detailed plans to achieve optimum balance of ore with the available resources. The planning process (a) identifies the goals or objectives to be achieved, (b) formulates strategies and tactics to achieve them, (c) arranges or creates the means required, and (d) implements, directs, and monitors all steps in their proper sequence. In the study, it was revealed that both global mine productivity, and MSV mine planning and design use software solutions to accomplish exploration and production of minerals. Mining software are used to approximate the mineral deposits by modeling, managing the infrastructure desirable for ore extraction or track the mining and fragmentation of ore throughout the mining cycle.

MSV mine uses surpac 2019 and AutoCAD 2013 whilst globally mine planning sections on underground mine productivity launched Micromine 2020 mining software, which is latest version of leading exploration and 3D mine design solution that introduce stope optimisation functionality. The new version of Micromine includes innovative upgrades to current modules and new functionality included in response to mining industry needs. The module specifically caters to the needs of underground mine planners looking to optimise mine design to ensure project profitability (Micromine, 2020).

\subsubsection{Surpac 2019 mining software}

The study revealed that MSV mine planning and design use underground stope optimization capabilities that provides ability to automate the generation of stope designs for VCR and SLC mining methods. Mine planning engineers generate multiple design options and analyze these to select the most optimal design whilst ensuring it adheres to mining constraints. The technology enables to optimize their strategic plans based on the selection of either value, stope tonnage or calculated value. The software allows for stope design constraints to ensure as little manual work is required at later planning stages, saving time and improving efficiency. (Geovia surpac, 2019).

Key features

- Determine the optimal underground mining areas in the form of stope designs

- Reduce time taken compared to other methods

- Maximize recovered resource value for underground mines

\subsubsection{AutoCAD 2013}

MSV uses AutoCAD, and deal with a number of different modelling standards, including solids, meshes and Point clouds. It improves ability to create associative drawing views from any $3 \mathrm{D}$ model that can be opened or referenced by AutoCAD. The software is able to open, modify, and document 2D and 3D CAD models from almost any source. This ability and flexibility make AutoCAD a 'safe' or go-to tool for any drafting office.(AutoCAD, 2013).

Generally, mine-planning process is one of the most tactical steps in operation toward achieving strategic goals in mine productivity issues. The section plays a pivot role and links in all technical services provided to mining operation personnel. These include surveying, ventilation, geological and geotechnical information.

In the study, two scenarios were considered for analysis to ascertain the importance of mine planning and its influence on production. These included:

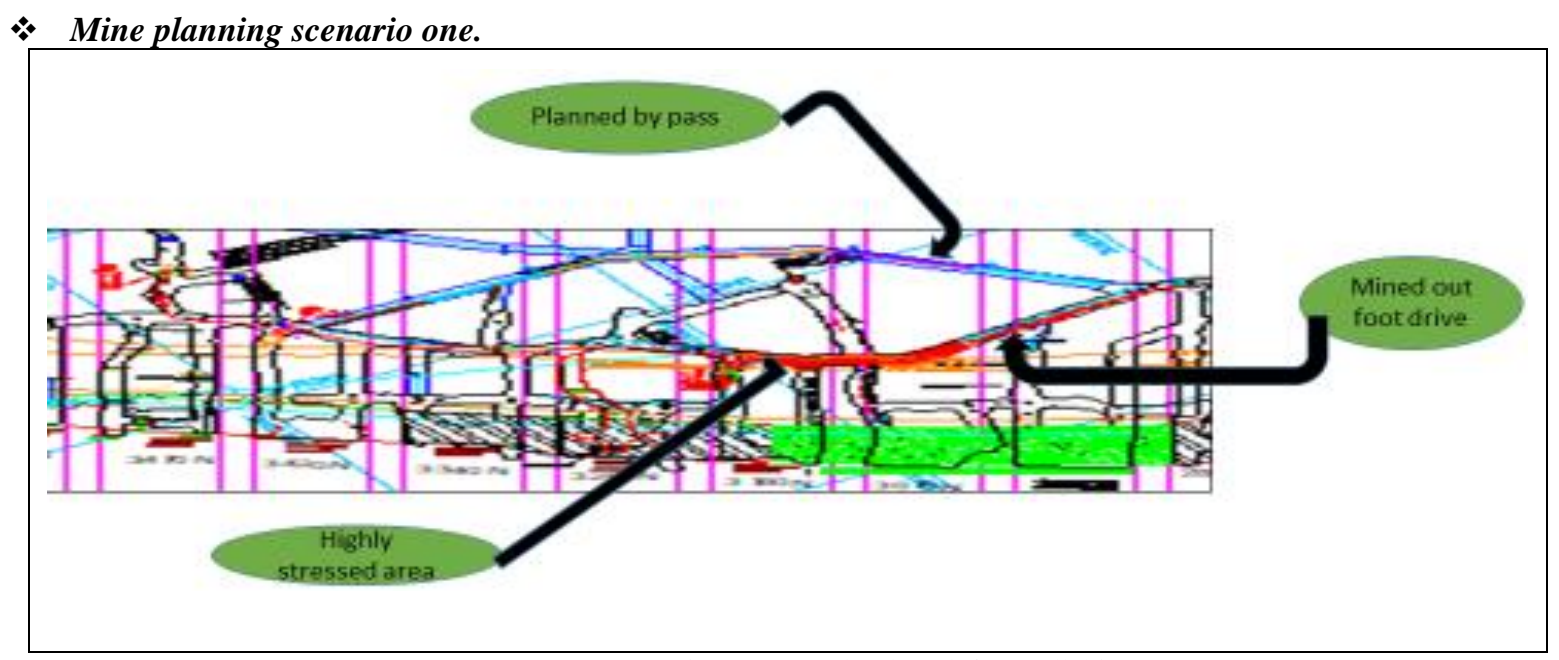

Figure 2: 4716 level north foot wall drive

Figure 2 illustrates a $4.5 \mathrm{~m}$ by $4.5 \mathrm{~m}$ excavation on 4716 level foot drive north at 3160 positon where three green flashing fog lights were installed to monitor the ground stability. Shortly, two turned red illustrating that the area was highly stressed. The affected area was barricaded off to pave way for investigations and findings where that at the time it was mined out there was no geological information as diamond drilling was not carried out in the zone to ascertain the rock. The planning team had no adequate information of the area, hence ended up making a layout 
that resulted into ground instabilities after excavation. Consequently, it lead to installation of extra support of the drive and redesigning of a 150 meters bypass to access imminent stopes and delays in both productivity and planned ore production the section.

\section{* Mine planning scenario two}

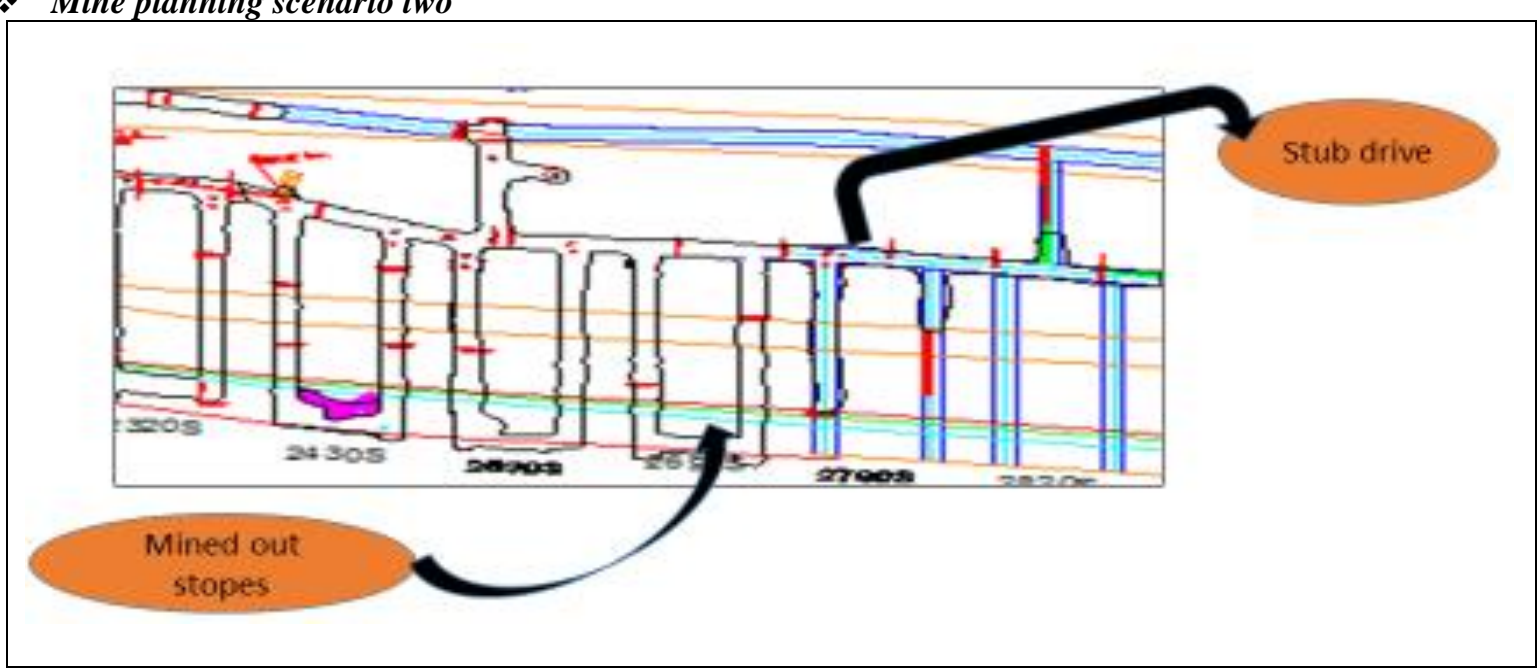

Figure 3: 4881level south stub drive

Figure 3 shows a similar $4.5 \mathrm{~m}$ by $4.5 \mathrm{~m}$ excavation on 4881 level stub drive south at 2690 positon were also three green flashing fog lights were installed and remained green showing that the area was stable. Prior to mining of the footwall drive excavation, geological information was availed to other technical personnel for their inputs hence resulted into flawless usage of planned support materials and no planned production interruption in the area.

\subsubsection{Geology}

In the paper, understanding MSV mine, the geology of the orebody and waste rocks is fundamental for successful resource estimation and the development of a defined mineral resource. As a result of this information, a plan for the extraction of a well-blended mixture of low and high grade ores can be made. This planning ensures that the mining process is prolonged, the removal of ore is optimised and the metallurgical processing plant, which will not work well if there are large grade variations, is able to operate economically and at consistently high levels of efficiency. The grade control officers (GCO) provide aid in ensuring grade control and adherence to loader tramming allocation. This somehow jeopardise achievement of planned grade targets as gco in some ore sources might be not be available for control.

Globally, all mines have set the most common parameters influencing dilution and ore losses in underground mining which include (a)Orebody delineation (b)Design and sequencing (c)Stope development (d) Drilling and blasting (e) (f)Production, and mine management issues (Lappalainen, 1996).

In the study, it was revealed that MSV geology section use software solutions to achieve exploration and control stope ore dilution. Geology software are used to estimate the ore deposits in production areas. These include;

\subsubsection{AcQuire geology software}

AcQuire software is used at MSV and widely regarded as the global leader in its field with many of the larger mining groups using acQuire in significant parts of their operations. It is a standard model for geoscientific data, which has been accepted as a global standard, in exploration, resource development, and mine production. The software is able to configure its application to meet the requirements of any project, while maintaining its standard model at the core. The acQuire data model 'governs' project data quality of exploration, resource development, and production and provides a global technical support network, learning courses, and a standardized process for software implementation. (AcQuire technology, 2018)

\subsubsection{Geovia Surpac}

In the paper it was revealed that MSV geology section also uses Geovia Surpac for underground exploration projects. The software provides efficiency and accuracy through powerful 3D graphics and workflow automation that can be aligned to company-specific processes and data flows. (Geovia, 2020).

While globally, in mine productivity and production, the geology sections use user-friendly soft wares such as Pitram grade control software, which is used in most of the mines to control and provide an overview of the issues influencing dilution in an underground production environment. Pitram's mining grade control software utilises mine design, survey and production data to provide real-time stockpile balances and metal stocks throughout the mining operation to assist with the accuracy of grade control. Grade control is critical to practical excavation plans. Any inaccuracies at this stage can cause major setbacks to operational and business performance. During exploration, grade control is a mining process to quality check and control the grade and variability of an ore. The purpose of grade control is for mining companies to 
understand and document any variability in their sampling and their ore reserve (Micromine, 2020).

\subsubsection{Ventilation}

Ventilation in the study is among the most important functions in an underground mining operation and requires the use of software. It provides a sufficient flow of air to dilute and remove dust and noxious gases and to regulate temperature to all underground working places and travel ways. The major sources of these gases are personnel, equipment that runs on diesel engines and blasting with explosives.

\subsubsection{VentSim soft ware}

The ventilation section at MSV use VentSim software which utilises intelligent software connected to hardware devices to remotely monitor, control and automate airflow, heating and cooling to deliver safer, more productive and lower cost ventilation mine. VentSim design creates an accurate simulation of the ventilation environment has animated 3D graphics representing actual airway dimensions and shapes with vigorous airflows. The software tool is useful in all stages of ventilation design, from assessing needs and selecting hardware in the early planning stages to ongoing optimization of everyday operations in a working mine. (VentSim, 2019).

While globally, most underground mines use Arctic Vent Control system, the system provides full control over airflow within the mining site. This advanced mine ventilation system has vehicle detection, gas detection, air quality sensors and scheduling possibilities that optimises the airflow underground. The ventilation system works independently and does not require any infrastructure in the form of Wi-Fi or other IT solutions. Due to its independence, Arctic Vent Control is easy to install and requires low initial costs. The system is also scalable, and each fan control unit is autonomous. That means the ventilation system, can be installed, and tested in one small part before continuing with installations throughout the mine.

Globally, ventilation directly affects the health and safety of employees working underground, it is therefore, imperative to take the regulation of airflow through a mine very seriously (Gefasystem, 2020).

\subsubsection{Survey}

Mine surveying determines the relative positions of points on or beneath the surface of the earth by direct or indirect measurements of distance and angles. It is responsible for maintaining an accurate plan of the mine as a whole and updating map of the layouts to account for new underground excavations and keep records of the mining operations. More importantly, the surveying is involved in the measuring process to calculate ore production, in volume or mass units, from the mining operation. In addition to this, the volume of the waste backfilled in the VCR stopes. In the paper, it was revealed that the latest survey software used at MSV is also the one used globally and it's called Amine data mine AutoCAD software.

\subsubsection{Amine data mine AutoCAD software}

MSV mine use AutoCAD-based mine design software called Amine is the perfect tool for all underground mine surveyors. It includes a complete suite of underground surveying tools including a laser offset function, automated cavity monitoring systems (CMS) slicing and underground monthly reporting summary. It streamlines and updates daily survey tasks whilst providing a more effective and timesaving reporting process. The software affords automated workflows that align with mines current productivity processes and requirements. It is flexible enough to be used for any ore body and mining method (Datamine, 2020).

\subsubsection{Geotechnical}

Globally, in all underground mines, and MSV in particular the prime functions of geotechnical engineering is to provide ground stability and support information to maintain excavation safety and access for their intended lifespan. The efficiency of a mine support policy is important for two main reasons, namely; safety to personnel and equipment, and to achieve the most economical extraction of ore. The type of ground support required in a particular location is dependent on several factors including the rock mass strength, the geometry of the excavation, the induced stresses, the blasting practices and the weathering process.

The control and management to address the risk of ground/strata failure is achieved through taking into account geological/geotechnical considerations in the mine design and planning processes and determining stresses with the aid of latest soft wares. Worldwide, this is achieved, among others, through gathering geotechnical data underground during site visits and routine underground visits by geotechnical engineering personnel. The undertakings include:

- Determining support distances and compliance to the standard;

- Determining excavation sizes and compliance to the standard;

- $\quad$ Determining support to face and sidewall distances;

- Damage mapping;

- Recording information on support installation quality;

- Recording information on blasting compliance;

- Recording general ground conditions;

- Recording information on prominent geological features; and

- Location of prominent structures.

4.1.6.1 Map3D Software

Mindola Subvertical mine uses Map3D, the program is able to accommodate a very wide range of problems in 3D. Large, complex, 3D problems are built with ease using the built-in CAD functionality. The various versions of Map3D fully support plastic fault-slip and 3D rock-mass plasticity, featuring compatible input files for all versions thus providing a clear upgrade path.

The program is fully integrated three-dimensional layout (CAD), visualization and stability analysis package. Various integrated program modules (Map3D Versions) is used to construct models, analyze and display stresses, strains, displacements, strength factors and probability of failure contours. Map3D is suitable for building and modelling rock engineering design problems involving 
both irregular 3D massive excavations, tunnels, faults and tabular shapes.

The stress analysis models simulate yielding (non-linear) zones of different moduli (e.g. stiff dykes or soft ore zones) and loads due to steady state thermal/fluid flow. Map3D simulate ground support elements such as arches, steel sets, props, thick liners, chalks and backfill. (Wiles, 2011).

However, globally most mines use Carlson software SDPS .It calculates ground deformations subsidence, strain, horizontal displacements and slope, based on the mine plan and geological characteristics. SDPS is a package developed through the Virginia Polytechnic Institute and State University (Virginia Tech) and Carlson Software is the world's only distributor. In this respect, all programs entirely use the central management of computer resources i.e. memory, use of the clipboard, peripherals. The package is designed to provide an integrated approach to the following problems (Carlson software, 2019)

- Calculation and prediction of ground deformations above undermined areas based on empirical or sitespecific regional parameters, the operator can calculate a variety of ground deformation indices according to the profile function method as well as the influence function method. The results are plotted using the graphing program provided, or exported to other graphing programs.

- Calculation of pillar safety factors for room-and-pillar.

\subsection{OPERATIONS FACTORS IN MINE PRODUCTIVITY}

Mine operations are vital in mining unit processes tactically in the forefront of productivity and production. The unit processes in mine operations determine financial viability of the whole operation. In the paper, after establishing the influencing parameters of productivity and production in all mining units processing, it was vital to analysis the performance of all contributing factors in causing deficits in ore production. The paper reviewed that overall productivity and production efficiency at MSV relate to tactic mining operations plans of day to day activities.

\subsubsection{Management and supervision}

Operations management and supervision at MSV is mainly concerned with planning, organizing, leading coordination and controlling (polcc) in the contexts of productivity and production.

It is delivery-focused; ensuring necessary improvements for advanced profitability and the mine successfully turns inputs to outputs in an efficient manner. The inputs could characterise anything as of materials, equipment and technology to human resources such as staff or workers. The alterations in the everyday tasks have to sustain the company's strategic goals. There are five main collections of happenings performed by operations management, deriving from its planning, organising leading coordination and controlling role. Activities involve considering assets, costs and human resources (Cleverism, 2018).
Whereas globally, operations management and supervision is not only focusing on "POLCC" but also concerned on managing fatigue of mine operations work force. The mine have formulated an integrated fatigue risk management system which falls within the safety management system. The conceptual approach starts with thorough preemployment assessments to identify candidates with a potential for fatigue and sleeping disorders. Underground mines have put up a requirement for regular review of organisational practices such as rosters and shifts to minimise the potential for fatigue, and also essentially provide employees education and training on developing the attitudes and skills necessary to manage their fatigue so as to enhance improvement in mine productivity and production.

Generally, it's equally important for operations management and supervisors to have opportunities to gain knowledge, skills and willingness to actively monitor, and to foster a culture that supports employee selfmanagement, and to take early and appropriate action where doubt exists about an individual's capacity to carry out their assigned production tasks safely and productively. Operation supervisors are responsible on the front line for detecting employee behavioral altitude as well as protecting the safety, productivity and bottom line profits of mining companies. Wikipedia. (2020). Management and supervisors must aim at improving the knowledge and skills to be able to effectively:

* Influence and oversight of staffing levels on employee performance;

* Schedule work to minimize the risk fatigue and production loses;

- Manage a team of employees to minimize fatigue risk within the group;

* Recognise warning signs of fatigue and understand company policies to address potential problems; and

* Perform periodic reviews of guidelines for achieving continuous improvement in the productivity production management program

Overall, in the study there needs to be an ongoing and effective strategy to promote employee capacity to manage underground productivity and production tasks; and to assist and manage employees whose fitness for work is compromised by fatigue. There is dual responsibility for productivity and production management between operation supervisors; and general workforce but the primary duty of care lies with the management and supervisors.

\subsubsection{Drilling}

Drilling is the most important phase of achieving good advance in development ends and if this is not done then any effort to enhance results by altering other constraints will be wasted. In the study, drilling is key in the development of excavation of totally non-valuable waste rock in order to gain access to the orebody. There are six steps involved in drilling of development ends and these include removal of previously blasted material, scaling down unstable slabs of rock hanging from the roof and 
sidewalls to protect workers/equipment from damage, installing support or reinforcement using shotcrete, drill face rock, load explosives, and blast explosives. During this stage, all planned power liability structures, drilling arrangement, dewatering, ventilation and muck withdrawal facilities are taken into consideration. The findings were as below;

\subsubsection{Marking of ends}

Development ends where not properly marked prior to drilling because of the following points;

\section{* $\quad$ Lack of standard drill pattern (Dopes)}

Men did not have a standard drilling pattern (dopes) for guidance to approximate the spacing, burden and precise position and design of cuts.

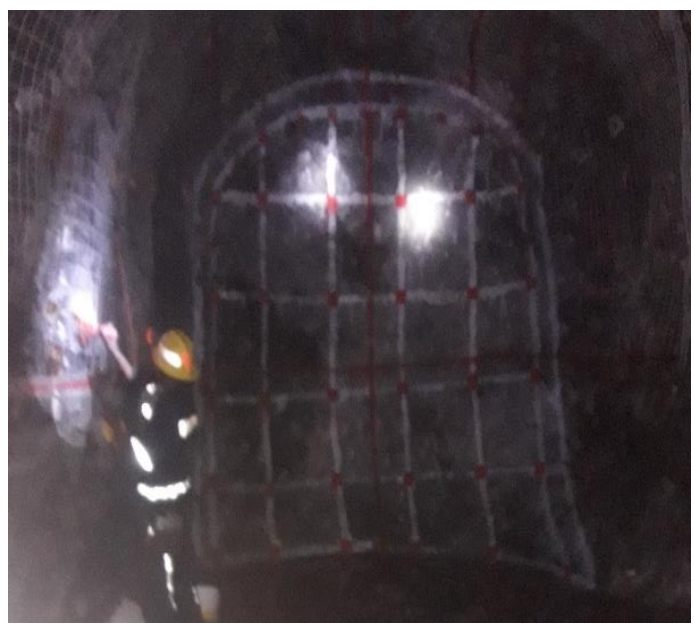

Marked end

Figure 4: Standard marked end at 4440level footwall drive

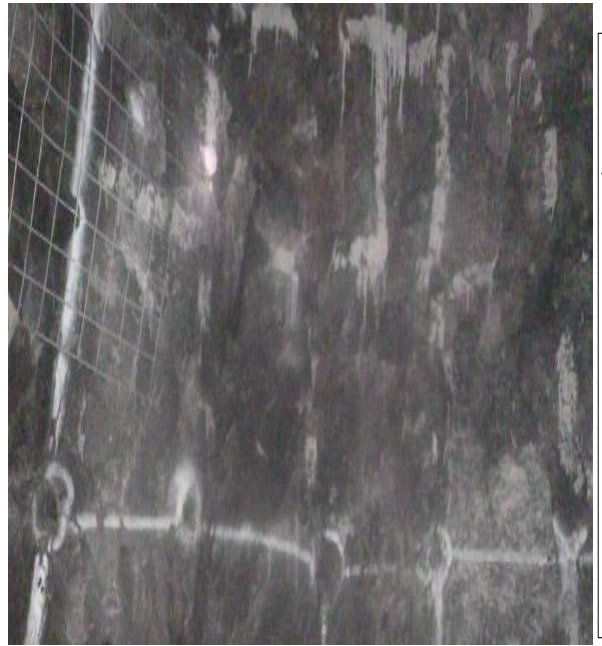

Marked end

Figure 5: Substandard marked end at $4881 / 2530 \mathrm{x} / \mathrm{cut}$

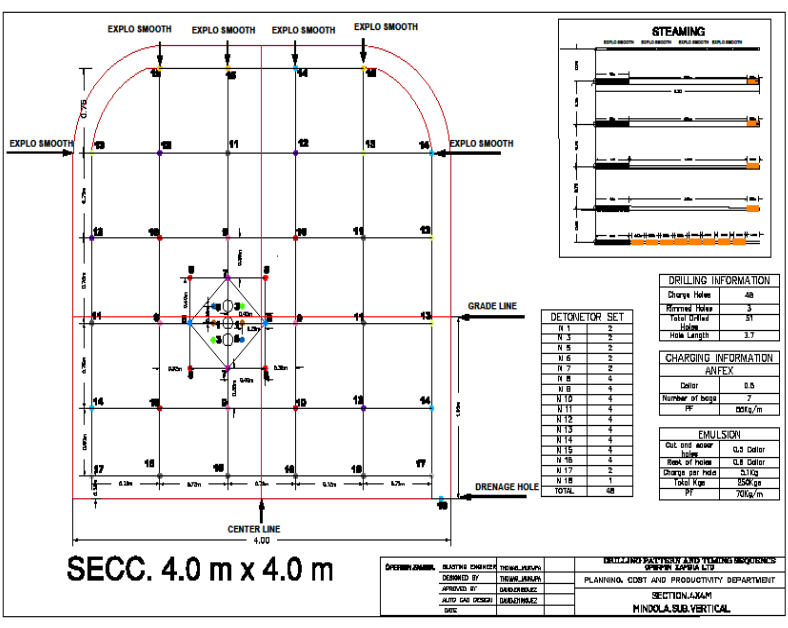

Standard layout

ranged from $0.9 \mathrm{~m}$ to $1.2 \mathrm{~m}$ as opposed to the standard $0.7 \mathrm{~m}$. This has great impact on achieving desired development outcomes.

\subsubsection{DRILLING COMPARISON}

Two ends were picked for analysis, one at 4440 level footwall drive and the other one at 4881level to ascertain smooth development of underground excavations. See figure 6 and 7 respectively. 


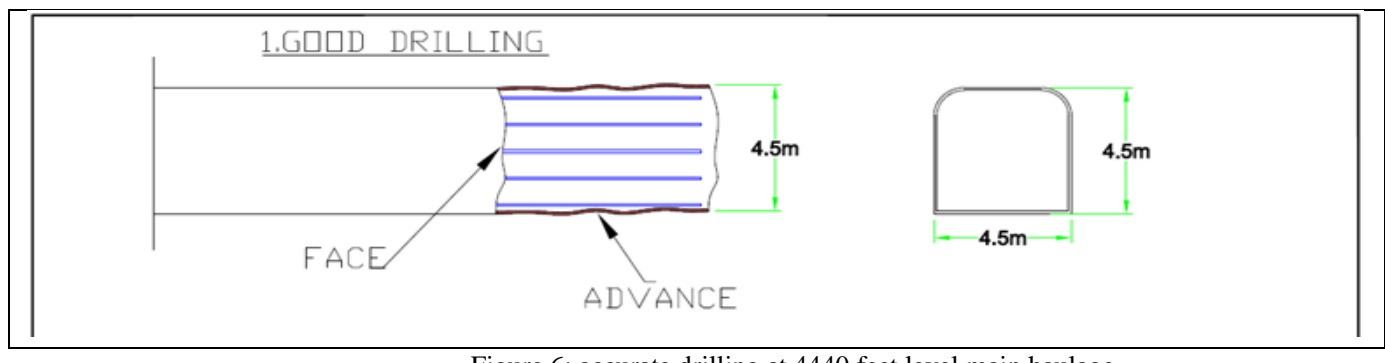

Figure 6: accurate drilling at 4440 feet level main haulage

Figure 6 demonstrated smooth opening which occurred within the designed periphery of tunneling. The excavation had even pattern of rock breakage this clearly revealed that end was work wisely drilled by a rig operator.

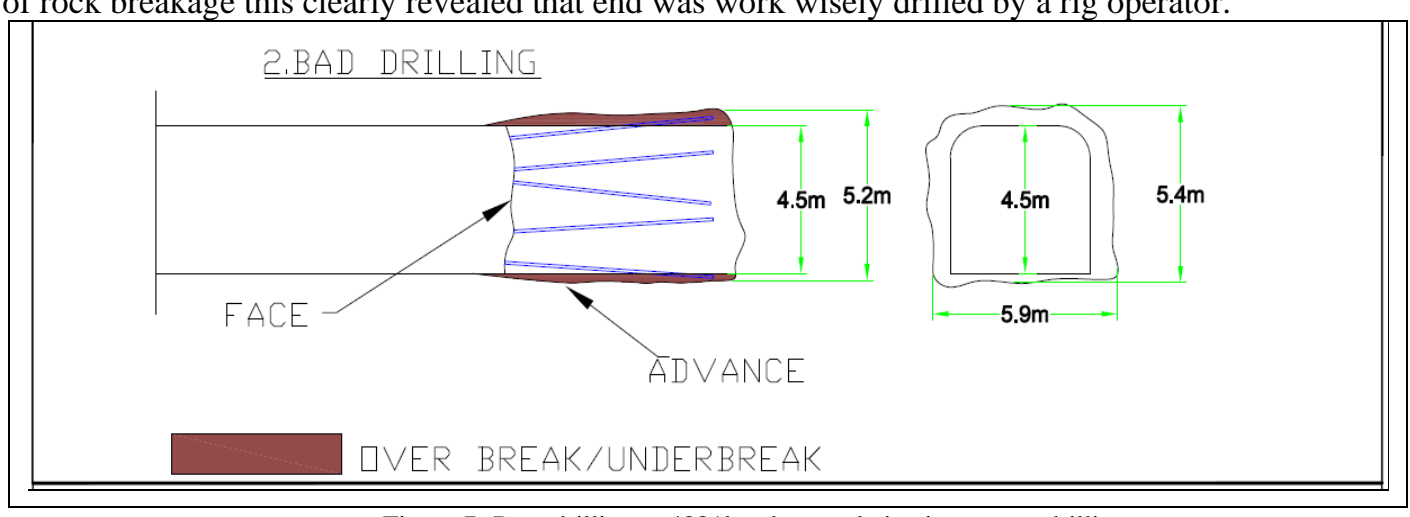

Figure 7: Poor drilling at 4881level -cumulative inaccurate drilling errors

In figure 7 shows over break that occurred outside the planned periphery of tunneling and showed irregular pattern of rock breakage. This clearly revealed that end was poorly drilled by a rig operator hence causing poor development anticipations.

In general, the parameter used to describe the advance of the excavation work is called "pull" or advance per round, or yield per round. Currently, the advance per round at MSV Mine is at an average of $2.8 \mathrm{~m}$ per round with a relative advance of $90 \%$ which give an average socket length of $0.9 \mathrm{~m}$. The allowable socket length is approximately $0.3 \mathrm{~m}$.

The round length is $3.7 \mathrm{~m}$ and the length of the drill rode (jumper length) is $3.7 \mathrm{~m}$ with a $0.2 \mathrm{~m}$ of collaring. The mine is currently using $45 \mathrm{~mm}$ drill bits (button bit) for both ore and development ends.

\subsubsection{Primary Development}

In the paper, all excavations at MSV required to access the ore body and support mining operations are considered as long-term development and bigger in size. These include infrastructure development and associated ancillary development. Refer to table 7, below.

* All declines and incline development

* All access drives

* All ventilation crosscuts

* All raise bore development

* All footwall drives up to $10 \mathrm{~m}$ past the first crosscut on each level

* Refuge bays, explosive stores, workshops, offices, clinics,

\subsection{3 .1 Secondary development}

The paper reviewed that secondary development are all excavations that exposes the ore body and which are required for short-term direct exploration of the ore body and are always smaller in size. i.e.

* All footwall drives and subsequent development from $10 \mathrm{~m}$ past the first crosscut position on each level.

* VCR chambers

Table 1 below displays the primary and secondary development areas.

\begin{tabular}{|l|c|l|}
\hline \multicolumn{1}{|c|}{ Description } & Primary - Secondary split & \\
\hline Development & Primary & Including ancillary development (boxes, cubbies) \\
\hline Tramming haulage & Primary & Including ancillary development (cross cuts) \\
\hline Water drive & Primary & $\begin{array}{l}\text { MSV - Including ancillary development (Raise bore cross cuts and } \\
\text { chambers) } \\
\text { Included in ancillary, mined at 70 meters interval }\end{array}$ \\
\hline $\begin{array}{l}\text { Level access development, ramps } \\
\text { etc. }\end{array}$ & Primary & Including auxiliary development (refuge cubbies) \\
\hline All other major infrastructure & Primary & $\begin{array}{l}\text { Development required to support ore flow, people flow and material flow } \\
\text { as well as to allow for the supply of services and the handling of water }\end{array}$ \\
\hline FW drive and crosscuts & Secondary & $\begin{array}{l}\text { MSV-The first 50m on each newly established level will be classified as } \\
\text { Primary development i.e. to allow access to the first stopes on each level }\end{array}$ \\
\hline Ore body drive & Secondary & In SLC stopes at MSV \\
\hline
\end{tabular}

Table 1: Primary vs. Secondary Development Split 
Generally, in both primary and secondary development, a tunnel is advanced by blasting one to three rounds per day. The length of advance per round is limited by the quality of the rock and by the diameter of the excavation. The greater the tunnel diameter, the greater the release, and therefore, in general, the greater the advance or pull that can be achieved in any given quality of rock. Pull varies from about $0.5 \mathrm{~m}$ in very broken ground that requires immediate support, to as much as $3 \mathrm{~m}$ in massive and self-supporting rock in a large diameter excavation.

In the paper, it was observed that currently, MSV mine has been experiencing development poor advance per round "pull" or yield per round. On average, the advance per round was $2.8 \mathrm{~m}$ out of a jumper length of $3.7 \mathrm{~m}$ leaving a socket length of more than $0.9 \mathrm{~m}$. The major causative factors leading to poor advance has been lack of; consistency length drilling of face holes as per standard layout, stemming drill holes, cleaning drilled holes, proper timing, Therefore, the optimization goal of both developments should be exertion on the highlighted possible factors that lead to the poor advance so as to improve advance per pull. For the mine to have a sustainable ore production, the study identified the following ends as critical. (Bwalya, 2019).

\begin{tabular}{|l|l|}
\hline CRITICAL DEVELOPMENT ENDS & PURPOSE FOR MINING \\
\hline MIN_4881L_5045L_1980S_DECLINE_1_S_P & To mine second access as required by the law \\
\hline MIN_5220L_HLG_S_P & $\begin{array}{l}\text { Reduce long tipping distances by utilising chute boxes to } \\
\text { enhance production. }\end{array}$ \\
\cline { 1 - 2 } MIN_5570L_RAMPL_ACCESS_HOTHOLE_UC & $\begin{array}{l}\text { Provide access to the existing shaft bottom for spillage lashing } \\
\text { during production build up towards steady state. }\end{array}$ \\
\cline { 1 - 2 } MIN_5650_900N_DECL_MRAMP_1_N_UC & $\begin{array}{l}\text { Access to the life of mine reserve, tramming haulage, water and } \\
\text { ore handling facilities }\end{array}$ \\
\cline { 1 - 2 } MIN_5650_900N_DECL_MRAMP_1_N_UC & \\
\cline { 1 - 2 } MIN_5570L_5956L_800S_DECLINE_S_P &
\end{tabular}

Table 2: MSV critical development ends

Whereas globally, development is classified into tunnelling and mining development. The underground excavations include horizontal tunnel development, incline tunnel development, ore pass development, vertical ventilation holes, silos and the drilling of drain holes. The mines use modern equipment in production areas and latest technologies used in drilling rig operation that nurture general mine productivity outcomes. The rigs are more proficient and effective as regards to where the mining business is headed in the future.

For instance, firstly HPE the drilling rigs used for horizontal development and incline tunnel development ensure faster drilling and have had a marked impact on safety due to the operator drilling from a safe and supported area. Drilling rigs for ore pass development (up to $55 \mathrm{~m}$ ), drilling of drain holes (up to $140 \mathrm{~m}$ ) and reef boring (up to $30 \mathrm{~m}$ ) use water operated DTH hammer technology. Holes are drilled from the bottom up and the drilling rigs are small enough to drill from a $3 \mathrm{~m} \times 3.5 \mathrm{~m}$ tunnel, thereby eliminating the need for increasing the excavation size. (HPE RIGS, 2020).
Secondly, DF30-1BCDL drill jumbo used by Zublin International in Chile, which works, as a contractor for the state owned mine is one of advanced high technology rig in underground mines. This equipment uses all hydraulic drive, with high efficiency and speediness, which can drill $0.8 \mathrm{~m} / \mathrm{min}$ to $2.5 \mathrm{~m} / \mathrm{min}$. The advanced hydraulically wellordered drilling system, which is easy to maneuver, incorporates the auto stop and anti-jamming function, autostop at end-point, auto wash. The rig has a minor frame, runs with the wheels, can reach a speed of $8 \mathrm{~km} / \mathrm{h}$ functioning by electric motor. It also reduces noise, dust and energy consumption on the machine. The rig works on the section, roof, side and floor. The machine cannot only drill blast holes, but also do support in excavations (Epiroc, 2017).

\subsubsection{STOPING}

Stoping is done in three production mining sections defined at Mindola SV Shaft with planned intervals between respective planned levels. See table 3 displaying stoping mining sections. 
Table 3: Stoping Mining sections

\begin{tabular}{|c|c|c|c|c|}
\hline $\begin{array}{l}\text { Mining } \\
\text { sections }\end{array}$ & Level top & Level bottom & $\begin{array}{c}\text { Vertical distance between } \\
\text { levels }\end{array}$ & Comment \\
\hline \multirow{3}{*}{ Upper } & 4020 & 4100 & 35 & \multirow{13}{*}{$\begin{array}{l}\text { Regional Pillar (crown } \\
\text { pillar) of } 40 \mathrm{~m}\end{array}$} \\
\hline & 4100 & 4180 & 35 & \\
\hline & 4180 & 4370 & 55 & \\
\hline \multirow{5}{*}{ Lower } & 4370 & 4440 & 21 & \\
\hline & 4440 & 4552 & 34 & \\
\hline & 4716 & 4881 & 50 & \\
\hline & 4881 & 5045 & 53 & \\
\hline & 5045 & 5220 & 50 & \\
\hline \multirow{5}{*}{ Deeps } & 5220 & 5345 & 40 & \\
\hline & 5345 & 5485 & 43 & \\
\hline & 5485 & 5650 & 50 & \\
\hline & 5650 & 5814 & 51 & \\
\hline & 5814 & 5956 & 43 & \\
\hline
\end{tabular}

Table 3 shows the block between 4716fL, 5220fL and Deeps area which applies this VCR method and other areas of the mine above 4716fL apply transverse SLC (sublevel caving) mining method. As the required production tonnage increases and mining progress deeper, more ore will come from below 5220fL, area known as the Mindola Deeps. See figure 8 for illustration.

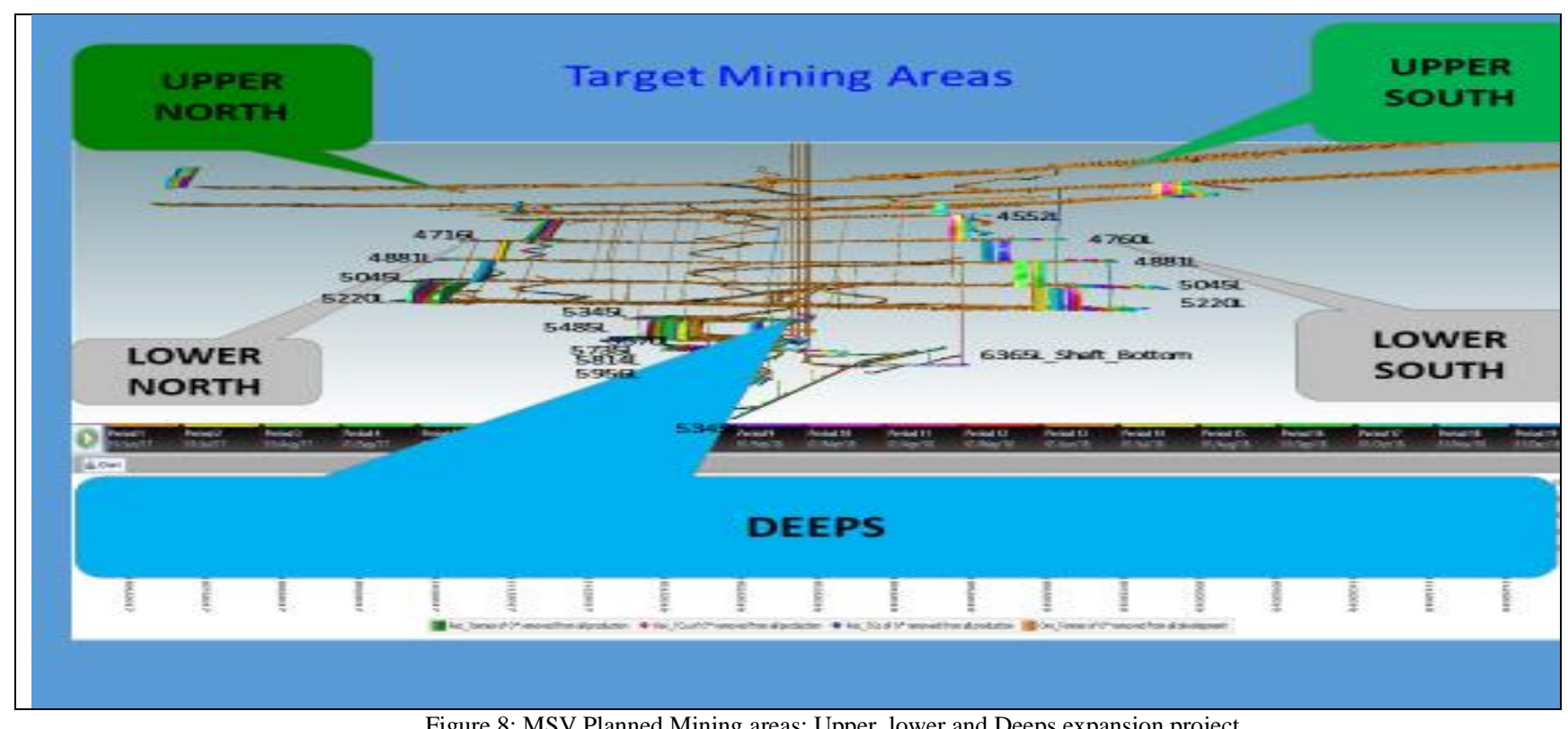

Figure 8: MSV Planned Mining areas: Upper, lower and Deeps expansion project.

\subsubsection{Vertical crater retreat (VCR)}

The main mining method employed at MSV is VCR with un-cemented waste rock fill. A vertical crater retreat also referred to as 'vertical retreat mining, involves drilling large-diameter holes into the orebody vertically from the top of the mine, as opposed to the conventional blast hole Stope method of drilling them in fans from bottom to top. (Goel. S.C)

A stope size is typically $25 \mathrm{~m}$ in strike with a $7 \mathrm{~m}$ thick rib pillar and a $50 \mathrm{~m}$ vertical stope height. The width averages 16.0m.The Rib Pillars are not mined but left in-situ without mining. To manage and control stress build up, the stoping sequence is a systematic retreat from the center out and then upwards. The lowest panel mined out progresses out to almost the distance of the stope height and creates a 45 degrees angle between the top and bottom lift panels more of a pyramid echelon.

VCR stopes are $25 \mathrm{~m}$ along strike, $50 \mathrm{~m}$ high and ranges in thickness depending on the orebody thickness from approximately $7 \mathrm{~m}$ to $15 \mathrm{~m}$. Between every VCR stope is a $7 \mathrm{~m}$ thick rib pillar, see (Figure 9: Plan of the VCR development layout). The purpose of this pillar is to enable sequential stoping, i.e. containing the waste material used to backfill the previously mined stope whilst the following stope is extracted. 


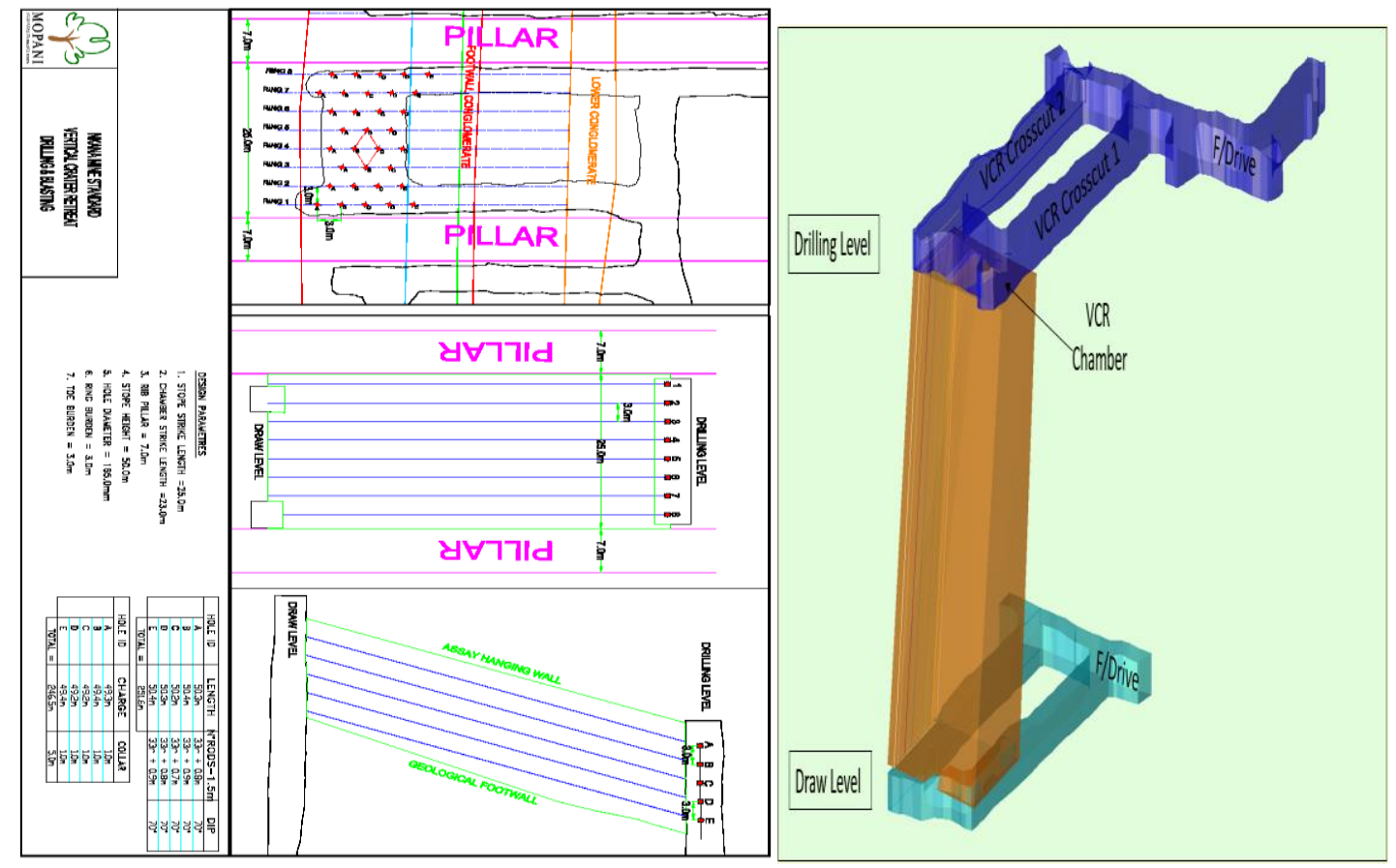

Figure 9: Plan of the VCR development layout

Long hole drilling is by means of down the hole drill rigs (Cubex rigs) from the overcut (top sill) excavation. 150mm diameter holes are drilled downwards breaking through into the undercut. Drilling performance has been affected by various parameters such as compressed air, temperature, labour, breakdowns and from time to time site availability.
The highlighted issues which heavily contribute on the poor performance of the cubex machines and if worked on would impact positively on the machine performance. Figure 10 illustrates the importance of good VCR chamber drilling in ore production.

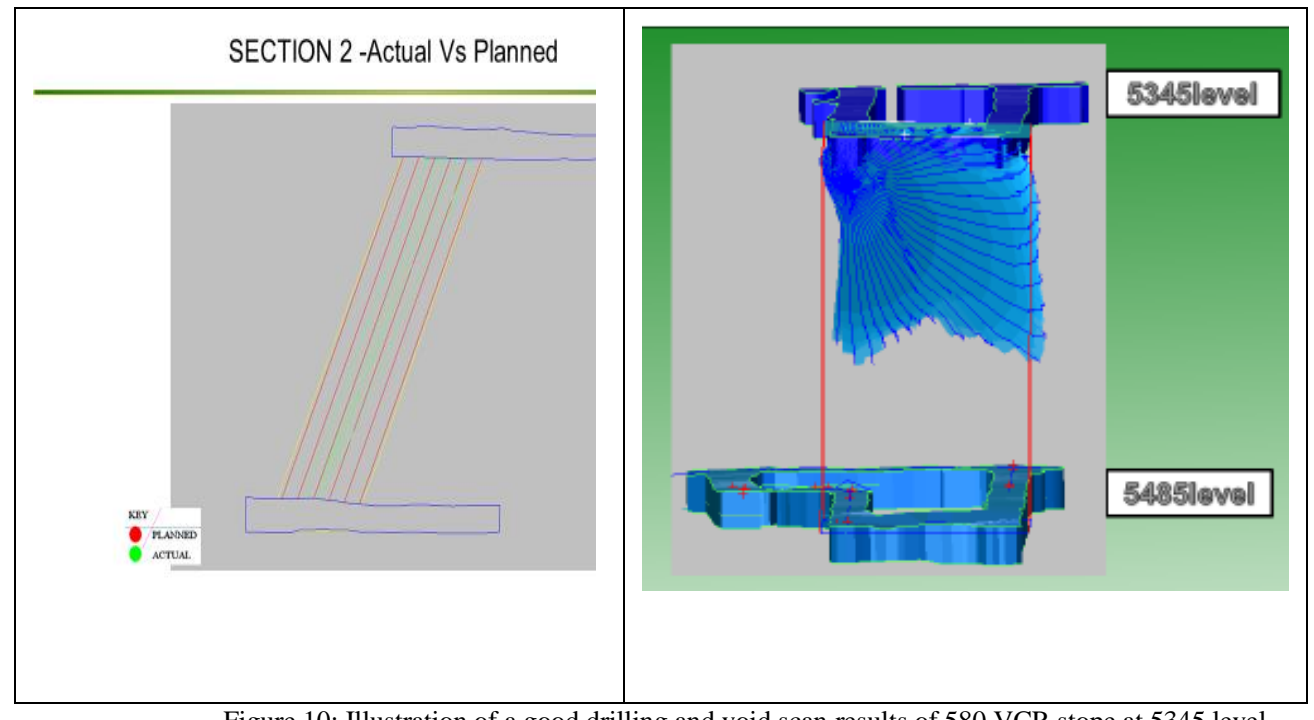

Figure 10: Illustration of a good drilling and void scan results of 580 VCR stope at 5345 level

Figure 10 shows VCR void after ore draw was within planned mining limits and surrounding environment stability. This is a decent case and control of drilling activities of good drilling as per standard drilling lay out leading into quality work. 


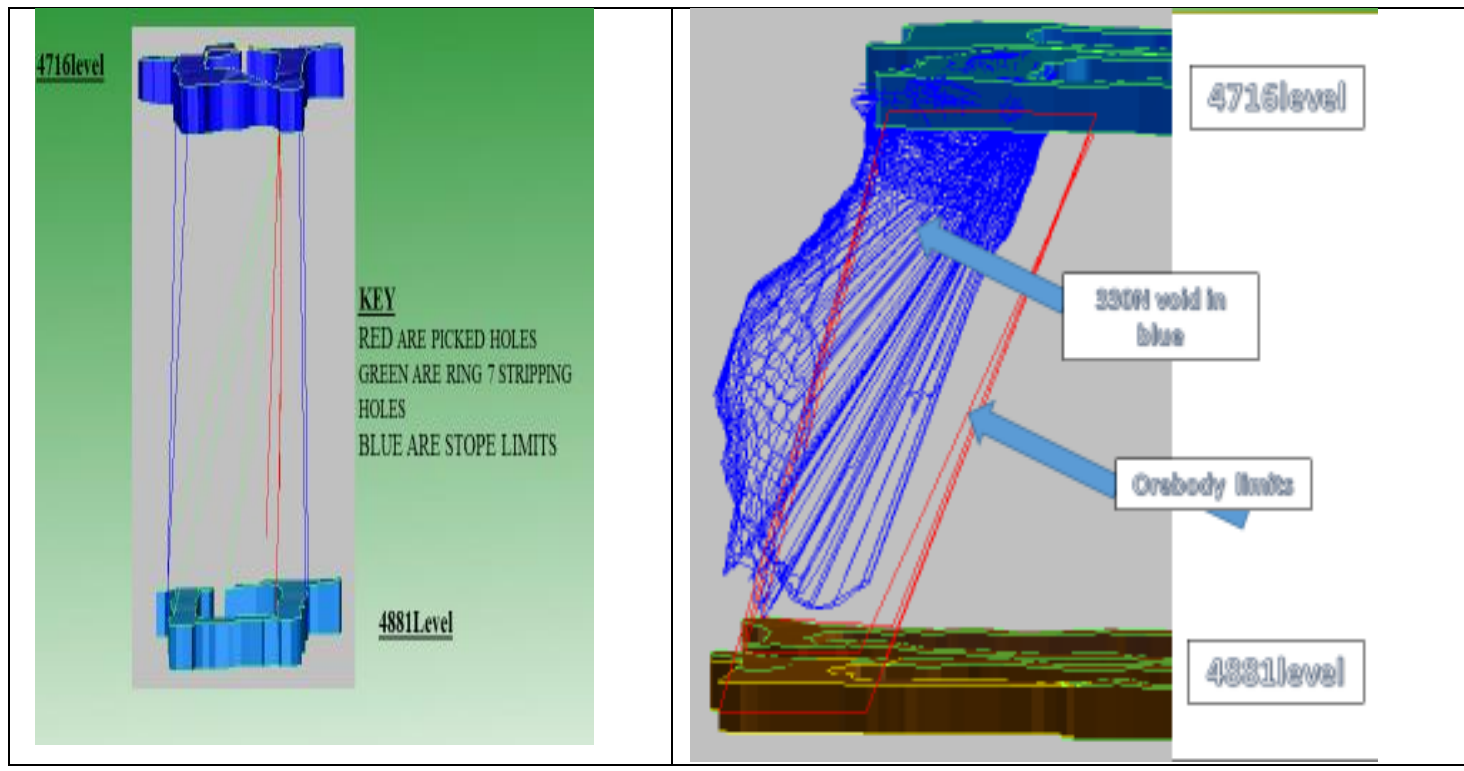

Figure11: Illustration of a bad drilling and void scan results of 3340 VCR stope at 4716 level

Figure 11 shows similar VCR void but with risked hanging wall as result of hole deviations, this causes instabilities in the surrounding areas as more stress are induced in the rock mass.

Generally when related the two figures, it was demonstrated that good drilling is the most critical aspect of achieving good VCR advance in stoping as seen in figure 10 above where there was minimal hole deviation. This lead into desirable results of void scan results, less ore dilution and hence good stope recovery. Figure six depicted poor VCR drilling causing hole deviations and adverse void scan results. The hanging wall of $3340 \mathrm{VCR}$ stope was severely damaged hence triggered high ore dilution and lose of tonnage. From the two scenarios, clearly it was observed that control of machine percussion, compressed air and drill rig operator's skill are cardinal in VCR chamber drilling.

\subsubsection{Sublevel Caving (SLC)}

Sublevel caving in the upper section depends on sublevels with regular designs of drifts prepared inside the orebody at rather close vertical spacing (from $21.0 \mathrm{~m}$ to $45 \mathrm{~m}$ ). The drift layout is the same on each sublevel (i.e. parallel drives across the orebody from the footwall transport drive to the hanging wall) but the patterns on each sublevel are slightly offset so that the drifts on a lower level are located between the drifts on the sublevel above it. When the development of the sublevel is finished, the long-hole drill rig Raptor machine moves in to the chamber to drill up holes unlike in the vcr chambers where down holes are drilled. When all required holes are ready, the long-hole drill rig is moved out to enable blasting crews to procedure with the charging.

The long-hole blast breaks the rock mass above the sublevel drift, initiating a cave that starts at the hanging wall contact and withdrawals toward the footwall following a straight front across the orebody on the sublevel.

The blast fills the draw points front with ore and waste. When the Load Haul Dump arrives, the cave contains 99\% ore. As loading continues, the proportion of waste rock will gradually increase until the operator and mining officials decides that the waste dilution is too high and stops loading. Figure shows a typical Sublevel Caving Mining method. 


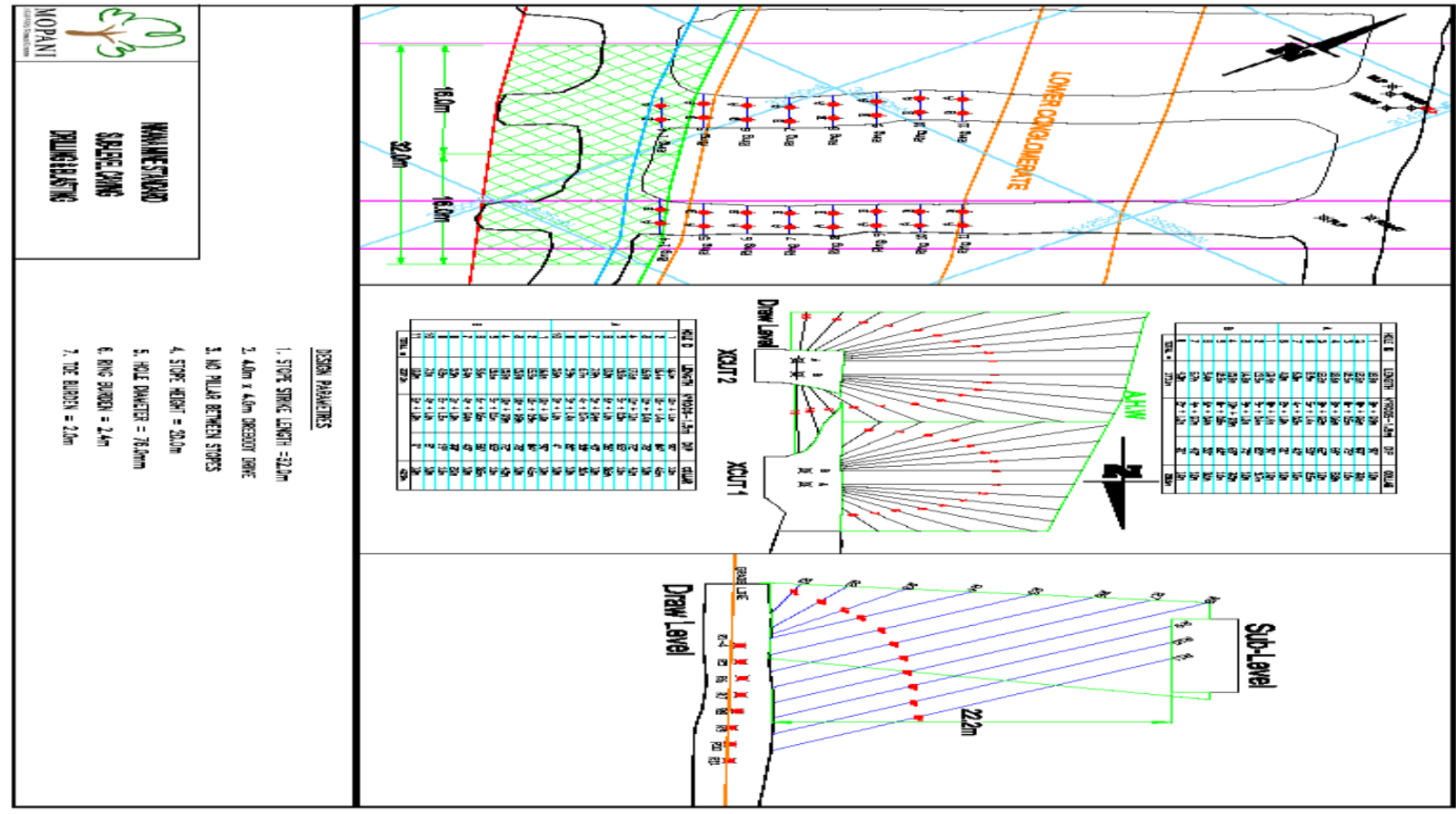

\subsubsection{Advantages of VCR over SLC}

Vertical crater retreat (VCR) is a beneficial Mining method because it reduces the cost of mining orebodies that are wide and steep. It also eliminates the need for a support system after the blasting occurs and increases mining safety of operations because drilling and blasting are carried out from above and there is no need for the miner to enter the actual stope. Higher tonnage per day and lower stoping cost. Lower development cost since it eliminates raise boring and slot-cutting. Improvement in fragmentation (the method yields lowest powder factor). Reduced labour requirements, drilling, and charging time. Reduced dilution and over break. And elimination of uphole drilling and up-hole loading of explosives

The SLC mining method, however, being less selective than other VCR, it requires more labour when charging, does not produce particularly efficient extraction rates. The cave includes some 15 to 30 of waste with a loss of ore ranging from 15 to $25 \%$.

However, globally in this paper, it is noted that a number of mines use different mining methods depending on the size and shape of the ore body i.e. Caylloma Mine in Peru uses cut-and-fill mining method, which is applicable in the mining of steeply dipping orebodies in stable rock masses. Canadian mining company (INCO) use VCR and is used all over the world in areas with competent, steeply dipping ore and host rock (Goel, 1988). The Homestake mine in South Dakota, North America is a VCR mining operation. Their switch from cut and fill to VCR mining has been a major factor in their increased productivity since the 1970s. VCR drilling rigs originates in many shapes, extents and models, manufactured by various companies such as Atlas and Sandvik.

\section{$*$ \\ In-The-Hole (ITH)}

Globally, stoping is done by latest ITH machines whose design goal is to make the most of ore extraction and lessen dilution with precise drilling of production holes according to the plan. The ITH drilling is popular for production drilling in open stoping, because of its productivity, and straight hole accuracy. Its technology can be used for drilling up holes and down holes. Features are reliable design with superior fatigue resistance, leading to longer service life and lower operating costs. In Canada, these machines are furnished with a powerful hydraulic rock drill, as well as a carousel storage for extension rods. In addition, drilling can be performed by remote controls, so that the operator may remain in a safe position can also be used for the blastholes, which operate by breaking the hard rock into small flakes and then blowing them clear using an exhaust system (Sandvik, 2016).

The features of the device were that it was using hydraulics to drill down the hole at a drilling diameter of $165 \mathrm{~mm}$ and depth of $54 \mathrm{~m}$ between the drilling and receiving chambers. The drill is the energy source and prime mover, which alters energy from its original form (fluid) into mechanical energy to activate the system. The rod takes the energy from the drill to the bit. The bit then breaks the rock mechanically to achieve penetration. Compressed air is the blushing medium in the DTH system. For downward drilling, gravity tends to pull the cuttings towards the bottom of the hole. This is why it is vital to offer annular velocity greater than the slip velocity, to be able to remove cuttings.

\subsubsection{Rock fragmentation}

Rock fragmentation in this context, is the measure of how the material is broken by explosive blast and the distribution of rock dimensions. In the study, two scenarios of dissimilar areas and diverse rock sizes where considered for analysis. Scenario one from 4881/1610 which consisted of fine fragmentation and scenario two from $5220 / 3580 \mathrm{vcr}$ that comprised boulders. See the two analyses below. 


\subsubsection{Rock fragmentation analysis one}

Work place: 4881/1610 VCR

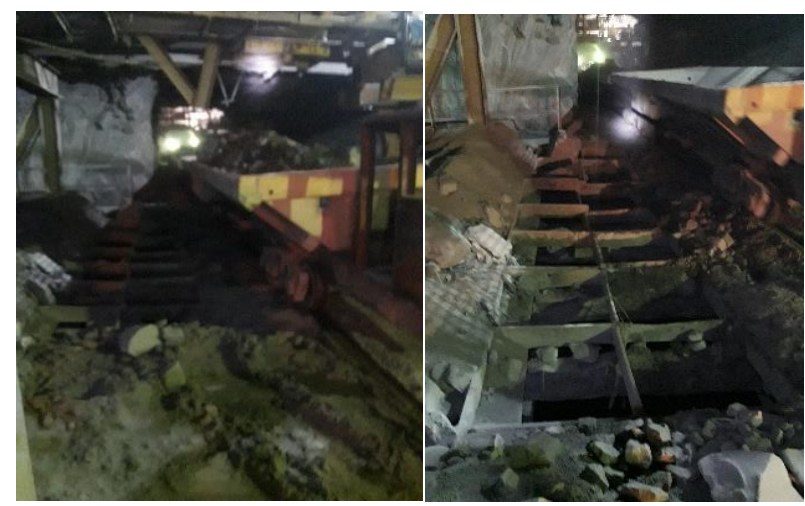

\begin{tabular}{|c|c|}
\hline $\begin{array}{ll}\text { SIZE } \\
\text { (inches) }\end{array}$ & $\begin{array}{l}\text { Percentage } \\
(\%)\end{array}$ \\
\hline $0<1$ & 20 \\
\hline $1-4$ & 30 \\
\hline $4-7$ & 25 \\
\hline$>7$ & 24 \\
\hline
\end{tabular}

Figure 13: - Rock fragmentation-round 1(Fine ore tipped on 52201 grizzlies)

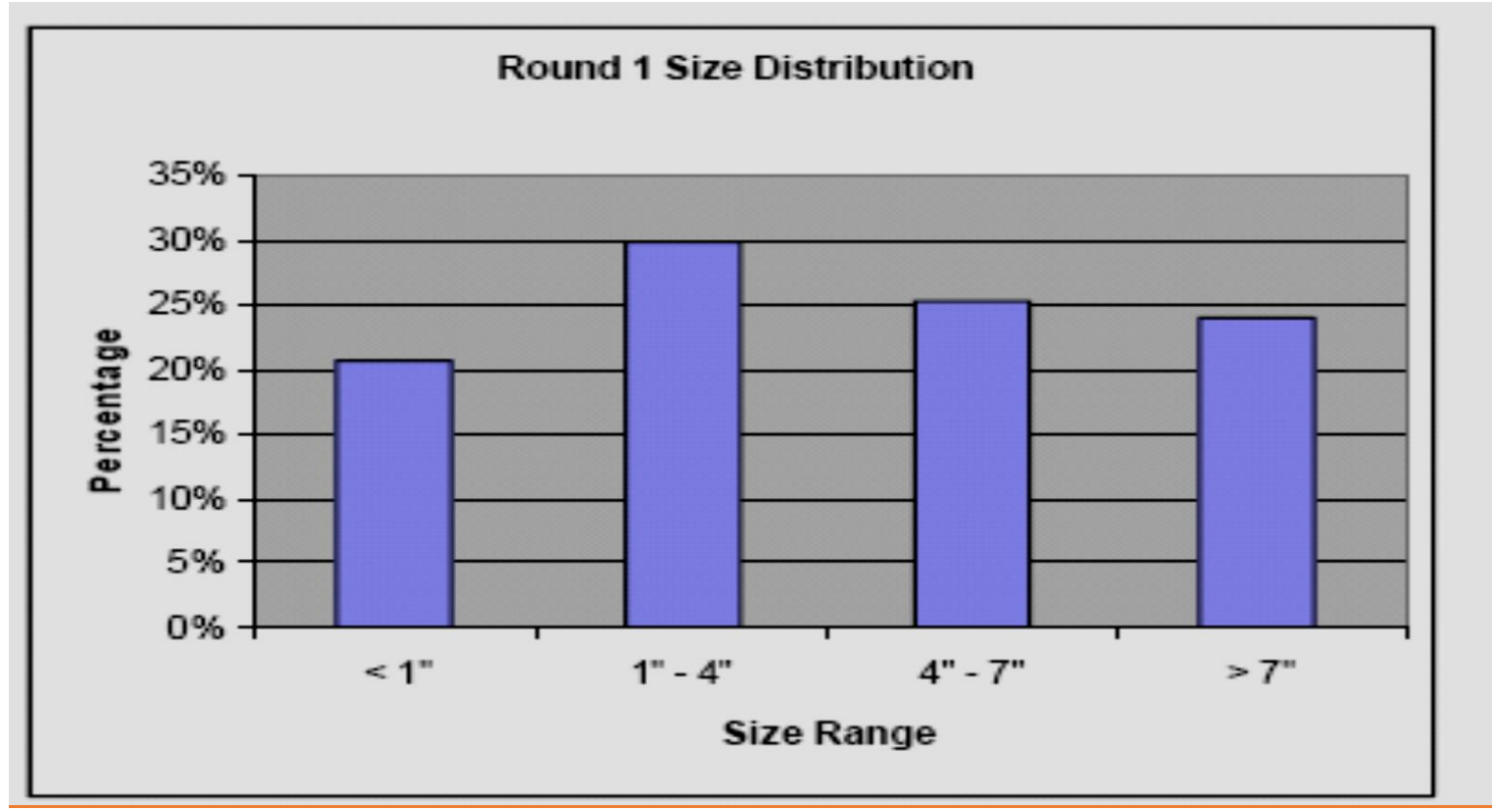

Figure 14: Size distribution of rock fragmentation-round 1

The analysis from 4881 level shows moderately even distribution across the size ranges, with a higher concentration of 1"-4" diameter rocks. This is a good example of proper fragmentation, as extreme sizes are minimal and the median sizes tend towards the smaller size. This took GM 07 locomotive 25 minutes to complete tipping ore into the tip hence exhibiting decent tramming cycle time. A larger amount of very small rocks would be as a result of too much explosives used in a round, leading to excessive costs. Conversely, lots of very large rocks signify a need for better blast design or more explosives loaded.

\subsubsection{Rock fragmentation analysis two}

Work place: $5220 \mathrm{l} / 3580 \mathrm{VCR}$

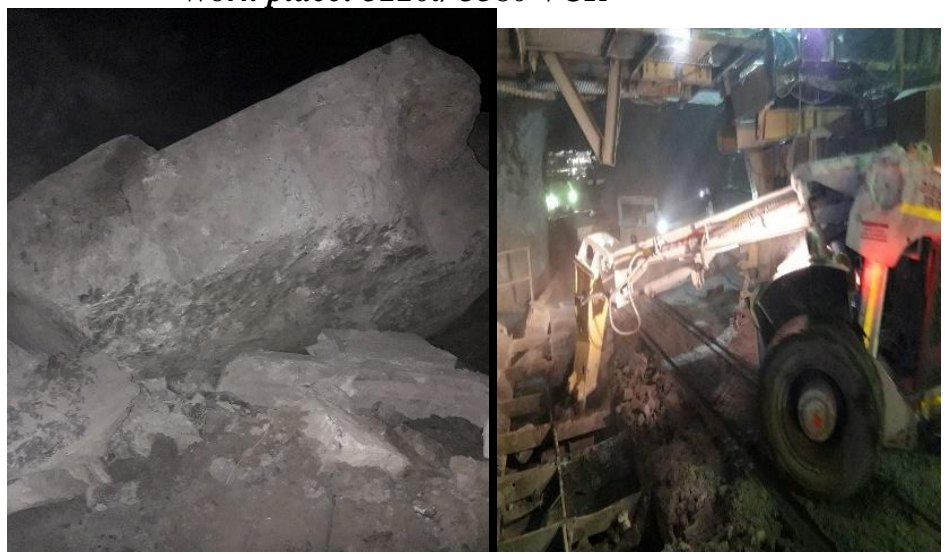

\begin{tabular}{|c|l|}
\hline $\begin{array}{l}\text { SIZE RANGE } \\
\text { (inches) }\end{array}$ & $\begin{array}{l}\text { Percentage } \\
(\%)\end{array}$ \\
\hline 0<1 & 20.5 \\
\hline $1-4$ & 26.5 \\
\hline $4-7$ & 30.5 \\
\hline$>7$ & 21 \\
\hline
\end{tabular}

Figure 15: Rock fragmentation-round 2 (Ore boulders tipped on 52201 grizzlies, Rock breaker) 


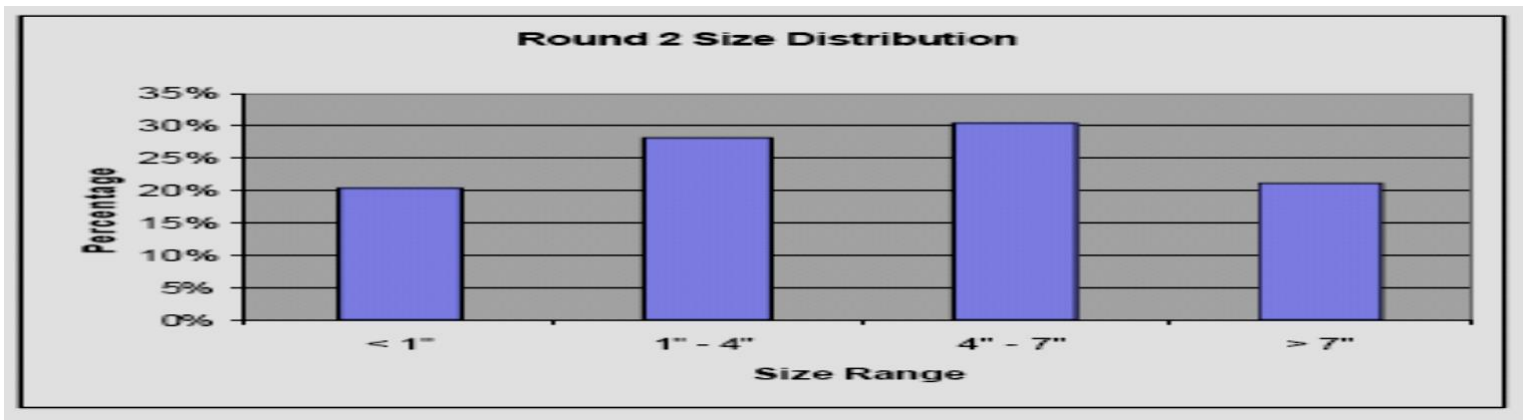

FIGURE 16: Size distribution of rock fragmentation-round 2

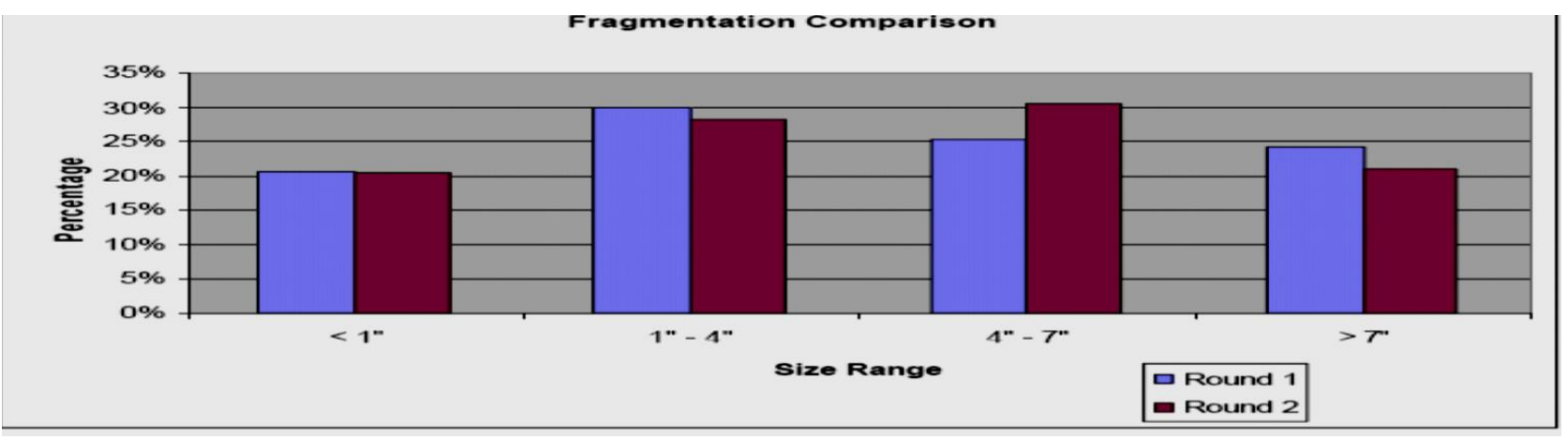

Figure 17: rock fragmentation comparison

Round 2 shows similar distributions in the extreme size ranges, but curiously trends to larger sizes in the middle ranges. This was considered bad fragmentation; the bias toward large sizes implies that the blast was less effective. It was observed that it took gm 07 one hour to finish tipping ore into the tip hence increasing tramming cycle time. When compared side-by-side, it is obvious that fragmentation was better in round 1. In addition to a smaller-trending distribution, the overall distribution was more even than in Round 2.

Overall, the degree of fragmentation plays an important role in loader lashing, on homogeneity of the boulder size in the workplaces contributes to increase scooping time as large boulders become difficulty to handle as compared to well fragmented materials, which in turn affects loader production, tonnage hauled per dump truck and tramming productivity. A fundamental economic requirement is to minimize the cost of any necessary process. However, the cost of the primary rock breaking process in underground mines cannot be considered in isolation. The aim should be to attain the lowest overall cost of the rock product through first stage crushing or, alternatively, onto the dump truck. All the associated process of breaking, loading, transporting should be considered collectively. The study indicated that inadequate fragmentation during primary breaking has led to expensive secondary breaking or spiral cost of loading, trucking and tramming. Therefore, for meaningful production improvement to take place, knowledge of blasting used at MSV mine is important.

While worldwide, currently charging is mostly done by using latest mobile charging units utility vehicles (UVs) which carry emulsion and supplied by a number of mining corporations such as SASOL, AEL, and BME. For instance, Daunia coalmine in Queensland, Australia, lately broke the global record for the biggest electronic detonator blast ever, firing 5665 detonators in 2683 blastholes, using BME AXXIS digital detonation system. The blasting crew used BME's blast design software, BlastMap III. The mine used a software that works in conjunction with the AXXIS Initiation System. The package enables intricate timing designs and analysis of the results for each blast. The advantage of the software is that it is easy to time the blasting designs, which can then be transferred directly to the detonators. This put results in a huge advantage in eradicating timing application faults, consequently eliminates high costs. The blast reflected a successful design because the designed limit is equal to the drilled limit and the built limit (Daunia Coal Mine, 2019).

Globally, blasting is one of the key components of mining activities and its significant outcome is fragmentation. Fragmentation is the first result of blasting that is directly related to the mining costs. The effective utilisation of the loader is assisted by employing optimised blasting practice i.e. blasting or degree of fragmentation of the in situ rock should be in such a way that loader buckets should not have difficulties in grabbing the blasted material or ground. Unfortunately, in the research it was observed that in some areas loaders more often than not grabs the problematic blasted material such that production has to standstill or delayed. The poor rock fragmentation occurs as a result of either poor drilling practice or poor blasting practice or both.

\subsubsection{Ore handling}

Mindola sub vertical mine has transformed its operation systems in accordance with the evolution of equipment, the system and method of mining. The study wide-open that underground ore tends to be very heterogeneous, the largest lumps often being over $1.5 \mathrm{~m}$ in diameter. The broken ore 
from the stopes, after blasting, is tipped into ore raise, in some areas it is loaded directly into trucks; holding up to 10 tons of ore in some cases, and is transported directly to the primary crusher. This always requires attention by having a effective framework on the controlling side.

Material handling can be complex for underground mining operations. The goal of mine haulage systems or material handling systems is to move rock masses from one location to another in the most efficient way while maintaining production rate and minimising operating costs. With many mining methods, structure, distances, and changing faces or draw points, it is important to understand appropriate material handling systems. These may include conveyor systems, locomotive tramming, scoop tram to trucking, and scoop tram from draw points to ore tips.

\subsection{4 .1 LHD Loading}

In the paper it was discovered that blasted ground coming from both development ends and stoping areas is scoped by LHD loaders such as Cat and scope tram machines. The productivity of the loader clearly depends on size of blasted rock material and operators efficiency For instance, a good blast, which resulted in good fragmentation for some hard rock, was easily loaded. It took 3 to 3 minutes for a 5 tones bucket capacity CAT 78 loader to scope ore from the draw points of the muck pile. However, the opposite was true where the same loader had to spend 6 to 7 minutes to scope ore for badly fragmented muck pile. The effective utilization of the loader is assisted by employing optimized blasting practice i.e. blasting or degree of fragmentation of the in situ rock should be in such a way that loader bucket should not have difficulties in grabbing the blasted material or ground.

While globally, a latest load haul and dump truck, also recognised, as scoop tram, is a machine used for loading and for applications in the mining business. Like the majority of the underground mining hardware, the structure of LHD is separated into two sections for improved distribution of weight amid activity. Its development with small height and width and long length encourages giving enhanced mobility to LHD in restricted passages. The new CAT $3000 \mathrm{H}$ LHD is also one of the advanced technology globally in loading of ore underground and offers an increase in truck loading capacity, enhanced digging and breakout performance, faster speeds on grade, a reinforced front frame, and an available ventilation reduction package that lower both machine and mine operating costs (Caterpillar, 2019).

\subsubsection{Haulage}

MSV Mine has two main types of hauling equipment for copper ore and waste material, namely dump trucks and Locos.

\subsection{4 .2 .1 Dump trucks.}

The observations were made on the effects of trucking of materials. Due to the relatively low broken density of the ore at MSV, several difficulties have been experienced. The main ramp in the deeps section is experiencing constant stopping and starting of the trucks due to traffic in the decline from 5130 level ore tip to 5570 loading level hence resulting in major production delays. There are four dump trucks on fleet to haul ore and three development contractor's trucks on waste. This, by large affects the overall production.

* Due to distance variation in some cases, especially in the upper section of the mine where the distance is more than $1.5 \mathrm{~km}$, time cycle of trucking ore to the ore pass is critically affected.

* Generally 3-4 cat bucket can be accommodated in ADT 07 and 08 however, the inclusion of the fourth often leads to spillage whilst the ADT is trucking up the main ramp if the load is not distributed correctly. It is for this reason that the LHDs generally only load two buckets resulting in the trucks being "under-loaded". This is due to the load unevenly distributed in the bowl.

* Due to the fact that the LHD operators are only loading two buckets per truck bowl, they will often neglect to "flatten" the load of the truck, using the bucket. This leads to an unbalanced load and can increase the chances of spillage from the bowl during trucking.

While globally, the paper noted that mining trucks keep on getting better and bigger, as miners progressively decide for huge capacity trucks with greater operational efficiency. One of the latest dump trucks include the following.

\section{Belaz 75710}

Recently launched, the Belaz 75710 is by far the world's largest underground dump truck, with the capacity to haul an amazing 496 tons of payload. The Belarusian Company Belaz launched the ultra-heavy dump truck in October 2013. The truck is 20.6 metre long, 8.16 metre high and 9.87 metre wide. The empty weight of the vehicle is 360 tons. Belaz 75710 features eight large-size Michelin tubeless pneumatic tyres and two 16-cylinder turbocharged diesel engines. The power output of each engine is 2,300 HP. The vehicle uses an electromechanical transmission powered by alternating current. The topmost speed of the truck is $64 \mathrm{~km} / \mathrm{h}$ (Wikipedia, 2019).

\subsection{4 .2 .2 Underground locomotives}

In the paper, a review of MSV locomotives was done so as to appreciate operation of locos in in production. Utmost time was spent on this part with the aim of observation of general operations of Locomotives so as to inspect the conditions of the locos and working environment, to find out the fill factor and daily targets, Inquire on significant risks associated with operating the locomotives, take note of challenges and reasons for failed to reach targets. See figure 18 of Locomotive. 


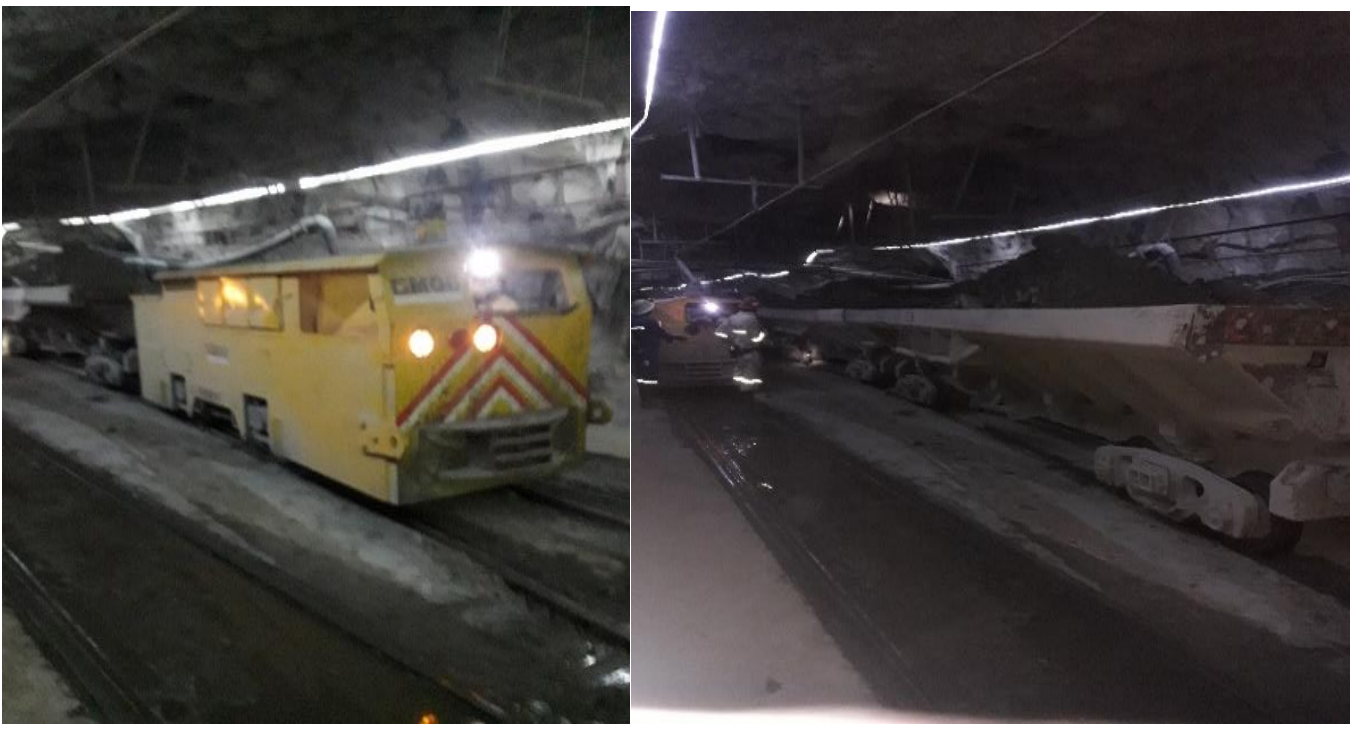

\subsection{4 .2 .2 .1 Observations.}

Figure 18: GM 06 Locomotive on 5220 tramming level

Material (ore or waste) is loaded into the tray cars using two methods. There is the side loading and loading from a chute box. Both of these methods have a number of advantages. For the chute box the advantages are that it loads the tray cars fast. It also fills the tray cars to a better capacity as it's not restricted by the size of the box. The box however, is not entirely dependent on the availability of a loader as long as there is material in the raise. The use of loaders to fill the tray cars is a good alternative if chute boxes have no material or not close enough to the production areas. It is proven to be better than a chute box because the broken rock size will not be completely limiting the loader from scooping. Therefore larger rocks can be loaded.
The rock sometimes is fragmented into smaller sizes. The ground therefore comes out muddy causing build up in the tray cars which have to eventually be pumped out using compressed air.

During loading of tray cars, (whether side loading or chute box) produces a lot of dust. Hence risking the health of the locomotive driver and whistle man with time. The dust is also produced during tipping.

The use of the trolley line is a continuous hazard and is used with great caution. The switch gear is there to power off the trolley line during maintenance or faulty trolley line sections. A link stick is also used in case the switch gear is powered back on without knowledge. Table 3 shows the locomotive mechanical availability.

Table 4: Locomotive mechanical availability

\begin{tabular}{|c|c|c|c|c|}
\hline No. & Fleet no. & Daily target(tonnes) & Availability \% & Fill factor(tonnes) \\
\hline 1 & T 55 & 400 & 90 & 10 \\
\hline 2 & T 43 & 400 & 70 & 10 \\
\hline 3 & GM 07 & 800 & 80 & 10 \\
\hline 4 & GM 02 & 800 & 80 & 10 \\
\hline
\end{tabular}

While globally, in the paper, a review of locomotives was done so as to appreciate global operation of locos in underground mines. Furthermore, to find out the fill factor, daily targets, inquire on significant risks associated with operating the locomotives.

\section{* Electric mining locomotive}

El Teniente underground mine in Chile use electric mining locomotives, fitted with four independently driven axles. The traction converter controlled travel motors allow the individual torque control of each drive axis. A highly efficient slip and slide protection system guarantees the optimum use of the available traction forces depending on the friction coefficient of the wheel-rail. The locomotive travels along tunnel sections that are completely automated with the help of an automatic train operation system via a serial interface of the locomotive control. At present, drivers control most of the electric locomotives used in the underground rail transportation. Reliability, efficiency, and safety are the common requirements for the underground ore handling (Armbrust et al, 2005).

\subsection{4 .2 .2 .2 Rail tracks walkover surveys}

Visual inspection of mine rail tracks were carried out checking for rail tracks noting tramming ways surfaces, drainage and alignment. The findings were as follows:

- The tramming ways varied. This affected time movement of locos for some portions due to the rails condition. Citing an example in this regards, the rails on main tramming levels both on north and the south retreats from loading points leading to apex are such a good example. 
- The rails are worn out,

- Some points of the tramming ways were found watery.

- Drainage in most areas was found to be poor and this affected the loco tramming ways.

The condition of the rail tracks continues to be a constant worry. It is one of the main reasons for derailments and loss of time. Production is directly affected by the rail track condition. It is positively affected when tracks are in good conditions, and negatively when tracks are in bad conditions. Considering the prevailing actual conditions of rail tracks at MSV, it is evident that production is not favoured and if no attention is given to the rail tracks, a worse situation of low production rate is likely to emerge. The non-existence of a rigging crew solely dedicated to derailments adds to the constant pauses in tramming operations. The poor condition of the locos causes constant breakdown and longer mean time to repair hours. The locos are old and can't pull the same tonnages as before. This further leads to increased cycle time and failed to reach targets. The coupling of the tipping arm to the cars when tipping tends to be a challenge and increases the tipping time. This is caused by the filling of cars with ground more on one side making the tray car lean more to the left. The car tray handle is then not aligned with the tipping arm.

The case of condition of rail tracks at $4440 \mathrm{ft}$ Level 1580 position, the rail tracks are waterlogged and this implies that no attention to track maintenance is given. The same applies to the case at $5220 \mathrm{ft}$ Level where rails are also waterlogged and this tells as to why breakdowns such as derailments are a common problem. The conditions of tracks have a greater bearing effect on cycle time of the equipment as the condition of the tracks becomes a limiting factor to the speed of the equipment. Though derailments may be caused by any of the following, track condition is the dominant factor:

- Collision of any type of carriages

- $\quad$ Large rocks obstructing the track line

- Spillage and other materials being on or near the track line

- Open car doors when in motion

- Rock and timbers reinforcing rods, scraper ropes protruding from the car

- Worn out wheel flanges

- Over speeding

- Applying brakes when the train is moving at a very high speed.

While globally, the water situation in the road ways leads to slippery surfaces and that creates the risk of slips and falls and vehicle accidents. Worldwide underground mines road maintenance are compacted and graded, and tactically it is the responsibility of the mineworker to execute road examination and to see the severity of potholes and water buildup on roads and report the road status to the shift bosses, who will delegate works to the team to maintain affected portions. Roads are constructed with due consideration for water damage and aimed at keeping them clean, pothole free and less damage of mine mobile machinery (TM3) tyres. Generally water is the main cause of road damage, for instance in Khutala seam east and west mine in South Africa, and the mine has worked on all underground tramming ways and this has improved on mining cost on tyres.

\subsubsection{Ore crushing}

Ore crushing is done at 5360 feet depth level by Gyratory primary crusher. It is solidly built to receive large lumps of rock directly from the 4440 level, 5130 level and 5220 level, and designed for large tonnage throughputs. The crusher reduce the size of large pieces of rocks produced during blasting in production areas. The mill crushes both ore and waste rock materials and consists of a cone-shaped burr rotating in the throat of a broad stationary funnel. There is no secondary crushing systems put in place to further reduce the ore sizes. Crushing of ore is not always attainable, due to its "long-ranged" particle size, sometimes metal objects like cubex bits cause difficulties during crushing, the fines working their way down through the voids between the larger particles; extremely coarse ore is sometimes difficult to handle and cause choker block in the ore stream.

While globally, in all underground mines ore crushing is done at different depth level by primary crushers; in some mines secondary crushing systems are put in place to further reduce the ore sizes. Crushing of such ore is not always attainable, due to its "long-ranged" particle size, which causes difficulties during crushing, the fines working their way down through the voids between the larger particles; extremely coarse ore is sometimes difficult to handle and cause choker block in the ore stream. For instance at Caledonia gold mine in Zimbabwe, broken ore is hauled along the 22 level rail system by battery locomotives and the ore cars trains are self-tipped onto one of three grizzlies above the ore bins, which are located between 22 Level and the 765 meter level crushing station. The minus $300 \mathrm{~mm}$ rock is held in three underground loading bins, payable ore and waste ore are held in distinct storage bins and moved accordingly. Ore is gravity fed from these ore bins onto the 765 metre level crushing station conveyor, which releases the ore onto a vibrating grizzly feeder, and discharges the oversize into a $30 \times 20$ Telsmith jaw crusher. The underground crushing station makes sure that all the run-of-mine ore is reduced to minus $150 \mathrm{~mm}$ in size as this provides for the optimisation and greater efficiency of the robotic skip loading and hoisting operations. This permits mining and hoisting of materials to carry on minus disruption (Caledonia mining, 2020).

\subsubsection{Hoisting}

The hoisting system is essential for the transportation of equipment, personnel, mined ore and, thus, for the productivity of the mine. It consists of various components in which there are winders, ropes and electric motors. For this paper, the assessment of hoist was done for shafts from surface to 2880 feet level and sub vertical shaft between 2880 feet level to 5500 feet level loading point through site visits of the hoisting systems, at various points. Doubling handling of crushed material from one shaft to another is a setback in both productivity and production. A cost effective hoisting system is a great call for MSV mine to 
enable ore handling from the underground to surface. With mining increasingly becoming a main contributor to economy, it has become necessary to improve mining to yield greater hoisting benefits.

Generally to improve on the hoisting, MSV mine is running a project that will handle material on a one way system, which is owned by diversified mining and marketing company Glencore's Zambian copper mining unit, Mopani Copper Mines. The project is done by a contracting company called Redpath Mining Africa raise boring and comprises two phases. The first phase involves the sinking, raise boring, equipping and commissioning of a 2 000-m-deep, 6.1-m-diameter shaft, while the second phase is to develop about $8000 \mathrm{~m}$ of primary access. Redpath was awarded the contract towards the end of 2012 and projected to complete by 2021. At Mindola Deeps, raise drilling of a vertical shaft in four lifts of about $500 \mathrm{~m}$ each has finalised. The shaft is constructed using raiseboring and directional drilling technology, with a portion from the surface involving a conventional blind sink.

A large shaft collar and bulk cold-air intake duct is also part of the construction works being carried out. The collar and cold-air duct have been constructed from a box cut of about $16000 \mathrm{~m} 3$ from the surface to a depth of $18 \mathrm{~m}$. The shaft has been blind-sunk and concrete-lined to a depth of about $85 \mathrm{~m}$ below the collar elevation. The shaft furnishing will comprise bunton sets at $6 \mathrm{~m}$ intervals, with $12 \mathrm{~m}$ steel guides. The permanent shaft configuration includes two hoisting compartments and a single man and/or materials compartment.

The bulk of the $10000 \mathrm{~m}$ access development is to establish a decline system from the existing 5 220-foot level to the bottom of the new shaft, but the development will also comprise equipping the new shaft with a crusher station, clear- water dams, silos and associated feed conveyors on the 6100 -foot level.

The Mindola Deeps project started with site establishment in July 2013 and the first underground blast was initiated on November 25, 2013. The problem in the project development is ground conditions being more challenging than expected and waste removal constraints, as a result the project's development targets have been inconsistently met.

Once the project is commissioned, the mine will inevitably reduce skip loading and material hoisting time, manpower costs, minimises spillage, increases hoisting capacity, ensures precise ore tonnage accountability, and enhances winder efficiency while lowering loading and hoisting costs.

While, generally all mines worldwide, the hoisting system is vital for the conveyance of equipment, employees, mined ore and, thus, for the efficiency of the mines. The maintenance and reliability of the hoist depends on its design, hence appropriate and accurate plan of a hoist is important. Globally, cost operational of hoisting system is a great call for all mines to enable ore handling from the production areas. Regionally, Blanket No. 4 Shaft has been equipped with the first automated loading system in Zimbabwe, which sequentially fills the two six tons ore skips which are hoisted from the 789 metre level to surface. The use of this state of the art automation reduces the risk of ore loading accidents and injuries, and also reduces manpower costs, minimises spillage, reduces skip loading times, increases hoisting capacity, ensures precise ore tonnage accountability, and enhances winder efficiency while lowering loading and hoisting costs (Caledonia mining, 2020).

\subsection{MAINTENANCE FACTOR IN MINE PRODUCTIVITY}

The purpose of this paper is to shed light on the various MSV underground mine maintenance activities and review the gaps between maintenance and operations. Maintenance section is the discipline that apply engineering concepts for the optimisation of mining equipment, procedures, and machinery budgets to achieve better maintainability, dependability, and availability of equipment.

\subsubsection{Management and supervision}

Generally, a maintenance process of equipment at MSV is important in maintaining reliability and availability concerning productivity and production. Maintenance decision make a direct impact on the economic aspect of the mines. Therefore, there is need for supervisors to lead an excellent upkeep of maintenance sections using planning and scheduling, best practices to drive work execution, and motivational and time-management techniques to improve maintenance worker productivity.

Globally, to have a good equipment maintenance policy, different mines have developed an efficiency operative program for handling assets. They have also put up action plans for supervision of human capital such as thriving to refining staff incentive, lower employee turnover, improved output and reduced waste of mine capitals (Life cycle engineering, 2020).

\subsubsection{Trackless mobile mining machinery ( $\mathrm{TM}^{3}$ )}

The general equipment- Trackless Mobile mining Machinery allocation to each section is entirely reliant on the production capacity of the section. Trackless Mobile mining Machinery is any self-propelled mobile machine that is used for the purpose of performing mining, transport or associated operations at a mine. MSV has a fleet of 13 loaders and 06 dump trucks of which the availability is very poor and greatly affect productivity and production.

\subsubsection{Underground mine workshop inspections}

Time was spent on the $\mathbf{T M}^{3}$ repair workshop at 4440level and 5220 level to understand its operations and evaluate its performance as regards to the role it plays in making machines available for ore production. Records of equipment being brought for repairs where examined to ascertain how responsive the workshop is to demands arising from the breakdown of machines.

The findings in the workshop were as follows:

* Careful consideration has been given to allow access to all the service points on the vehicles. There has also been a conscience effort to reduce the servicing time. 
As shown by the elimination of greasing points for rams, bin pivots and bin door hinges by the use of special greaseless bearing. The selection of basic truck "off the shelf" components where possible has had a significant impact on reducing the maintenance costs and parts availability.

* Mechanics at the workshop are qualified personnel but some lack the knowledge of making reference to output charts and tables - produced by manufactures.

* There are frequent breakdowns due to age of equipment

* There are some delays in repairing trucking equipment due to late reporting of faults by operators especially in the back shifts and lack of spares.

While globally, underground mine workshops maintenance facilities are mainly used as a position for service and repair of underground equipment. Underground shops are located in close proximity to operations to enable scheduled maintenance and emergency repairs on production machine works smoothly. Boliden Tara Mines Limited in Ireland owns and runs the biggest lead and zinc underground workshop in Europe and one of the largest in the world. The workshop facilities trackless mining mobile machinery and other motionless equipment components within underground.

\subsubsection{Lack of spares and approval procedures}

Machines at MSV are lacking standbys especially big spares like drive heads, compressors and engines. The machine are old and parts are worn-out therefore need to be changed. Sometimes a spare has to be taken out on surface for repair and taken back underground. This may take days, hence increasing on downtime hours for the machine.

Approval of spares is a nightmare even with the little budget allocated towards machine spares. In the paper, it was discovered that sometimes at underground workshops, even consumable spares such as hydraulic hoses, bolts and nuts are lacking.

While globally, available spare parts, service parts, repair parts, or replacement parts, are a compatible part kept in an inventory, used for the repair or replacement of failed units. Spare parts are an important feature of maintenance logistics used in productivity and production. Globally, spare part management ensure the availability of spares for maintenance in minimum time and reduction in searching time of spares, effective management of spare parts that gives satisfactory results to productivity and production. The inventory management involves specifying percentage of stocked goods that are required at all mine sites for stocking production material. Inventory management of different mining companies purchase and keep spare parts whilst ordering, shipping, handling, and related costs are checked. It also involves systems and processes that identify inventory requirements, set targets, provide replenishment techniques, report actual, estimated inventory status, and handle all functions related to the tracking and management of material. This includes monitoring of material moved into and out of stockroom locations and the reconciling of the inventory balances (Salunkhe et al, 2019).

\subsection{AUXILIARY SERVICES}

In the study, auxiliary services provide supporting role in production. Mine auxiliary services include diminutive productivity issues such compressed air, service water, pumping, dewatering. These issues have indirect or direct impact on msv production. These include:

\subsection{MINING WATER DISTRIBUTION}

Service water is tremendously vital resource for the both development and production at msv. As the mine deepens, there is a challenge to supply sufficient service water to the working faces. This has negatively affected rates on drilling productivity preceding into failing achieving planned targets and increase on down time claims by the developing contractors. Water supply issues are a result of aging infrastructure in the shaft, a cascade system has been drilled between levels and must still be cased to prevent seepage into the shaft. Once complete, water issues are expected to diminish. However, a mitigation plan is to make use of the water running from old stopes into service water dams and then piped in the section.

In general, mining service water control is a continuous process that needs to be settled and updated throughout the whole mine life cycle, for instance when changes in mining operations also affect the water stability and system should include water balance modelling and water quality and quantity monitoring.( Greenfield,2007).

\subsubsection{Mining water improvement plan}

The paper reviewed the current service water supply to the mine and found it to be erratic, insufficient in volume and lack the desired pressure required to sustain, not only the current operations demand, but also the capacity to meet the optimised operational demands for the near future. Currently the Mine has been facing challenges in terms of service water supply to the mine and this has led to contractors' failure to meet both development and Production targets. From the lost blast analysis compiled from Jan 2019 to December 2019 at MSV mine site, inadequate service water supply has contributed on average $11 \%$ to the contractors losing blast. The existing service water source to the mine is from out flows from old workings above the current mining and stoping horizon. The anticipation is that since the water out flow volume from this source has drastically reduced, eventually the flow will cut out; because of mining stoping activities, that is proportionately lowering the water table.

This study calls for rehabilitation of service water reticulation system at MSV to continuously supply water for mining. This project shall come with the following benefits to the mine;

- $\quad$ Production shall improve

- Development shall increase

- $\quad$ Cost of machine delays shall be reduced

- Machine Maintenance cost and time shall be reduced by ensuring machinery is supplied with clean water. 
Improvement of water service will be done by carry out the following activities:
1. Drilling a water service pilot hole from 4370 level to 4881 level. See estimated total cost of $\$ 113,162.27$ in table 4.

Table 5: Total cost of drilling a pilot service water hole

\begin{tabular}{|l|c|}
\hline \multicolumn{2}{|c|}{ Total cost of drilling for each level } \\
\hline Level & Cost estimate (\$) \\
\hline 4370L - 4881L hole piloting & $\$ 113,162.27$ \\
\hline TOTAL & $\$ 113,162.27$ \\
\hline
\end{tabular}

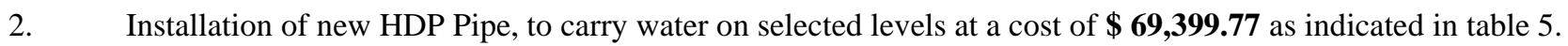

Table 5: Cost of Installation of new HDP pipes on selected levels

\begin{tabular}{|c|c|c|c|c|c|c|c|c|c|c|c|c|c|c|c|c|c|c|c|}
\hline \multicolumn{20}{|c|}{ Total cost for Pipe installation } \\
\hline \multirow{2}{*}{$\begin{array}{l}\text { Leve } \\
1\end{array}$} & \multicolumn{3}{|c|}{ Cost of 6" Pipes } & \multicolumn{3}{|c|}{ Cost of 4" Pipes } & \multicolumn{3}{|c|}{$\begin{array}{c}\text { Cost of Anchor } \\
\text { Chains }\end{array}$} & \multicolumn{3}{|c|}{ Cost of 4" Valve } & \multicolumn{2}{|c|}{$\begin{array}{c}\text { Cost of M16 } \\
\text { Bolts }\end{array}$} & \multicolumn{2}{|c|}{$\begin{array}{c}\text { Distanc } \\
\text { e of } \\
\text { pipe to } \\
\text { be } \\
\text { installe } \\
\text { d }\end{array}$} & \multirow[t]{2}{*}{$\begin{array}{c}\text { Refuge } \\
\text { Cham } \\
\text { ber } \\
\text { cost }\end{array}$} & \multirow[t]{2}{*}{$\begin{array}{c}\text { Labou } \\
\text { r cost } \\
\text { incurr } \\
\text { ed }\end{array}$} & \multirow[t]{2}{*}{$\begin{array}{c}\text { Cost } \\
\text { estima } \\
\text { te }(\$)\end{array}$} \\
\hline & $\begin{array}{l}\text { U } \\
\text { nit } \\
\mathbf{Q t} \\
\mathbf{y} \\
\end{array}$ & $\begin{array}{c}\text { Uni } \\
t \\
\text { Cos } \\
t \\
\end{array}$ & $\begin{array}{l}\text { Total } \\
\text { Cost } \\
\end{array}$ & $\begin{array}{c}\mathbf{U} \\
\text { nit } \\
\mathbf{Q t} \\
\mathbf{y}\end{array}$ & $\begin{array}{c}\text { Uni } \\
t \\
\text { Cos } \\
t \\
\end{array}$ & $\begin{array}{l}\text { Total } \\
\text { Cost }\end{array}$ & $\begin{array}{l}\mathbf{Q} \\
\text { ty } \\
(\mathbf{k} \\
\mathbf{g})\end{array}$ & $\begin{array}{c}\text { U } \\
\text { nit } \\
\text { C } \\
\text { os } \\
\text { t } \\
\end{array}$ & $\begin{array}{l}\text { Total } \\
\text { Cost } \\
\end{array}$ & $\begin{array}{l}Q \\
\text { ty }\end{array}$ & $\begin{array}{c}\text { Uni } \\
t \\
\text { Cos } \\
t \\
\end{array}$ & $\begin{array}{c}\text { Tota } \\
1 \\
\text { Cost } \\
\end{array}$ & $\begin{array}{l}Q \\
\text { ty } \\
(k \\
\text { g) } \\
\end{array}$ & $\begin{array}{c}\text { U } \\
\text { nit } \\
\text { C } \\
\text { os } \\
\text { t } \\
\end{array}$ & $\begin{array}{c}\text { Tot } \\
\text { al } \\
\text { Cos } \\
\text { t } \\
\end{array}$ & & & & \\
\hline $\begin{array}{l}4440 \\
\text { nort } \\
\text { h }\end{array}$ & & & & 29 & $\begin{array}{l}185 \\
.60\end{array}$ & $\begin{array}{c}5,382 . \\
40\end{array}$ & $\begin{array}{c}34 \\
8\end{array}$ & $\begin{array}{l}3 . \\
14\end{array}$ & $\begin{array}{c}1,092 . \\
72\end{array}$ & 2 & $\begin{array}{l}168 \\
.92\end{array}$ & $\begin{array}{c}337 . \\
84\end{array}$ & 3 & $\begin{array}{l}2 . \\
63\end{array}$ & 7.89 & 870 & & $\begin{array}{c}4,576.7 \\
1\end{array}$ & $\begin{array}{c}11,39 \\
0\end{array}$ \\
\hline $\begin{array}{l}4552 \\
\text { sout } \\
\text { h } \\
\end{array}$ & $\begin{array}{c}12 \\
0\end{array}$ & $\begin{array}{l}189 \\
.71 \\
\end{array}$ & $\begin{array}{c}22,765 . \\
20\end{array}$ & 24 & $\begin{array}{l}185 \\
.60 \\
\end{array}$ & $\begin{array}{c}4,454 . \\
40\end{array}$ & $\begin{array}{c}28 \\
1\end{array}$ & $\begin{array}{l}3 . \\
14 \\
\end{array}$ & $\begin{array}{c}882.3 \\
4\end{array}$ & 2 & $\begin{array}{l}168 \\
.92 \\
\end{array}$ & $\begin{array}{c}337 . \\
84 \\
\end{array}$ & 15 & $\begin{array}{l}2 . \\
63\end{array}$ & $\begin{array}{c}39.4 \\
5\end{array}$ & 700 & 13,527 & $\begin{array}{c}7,364.8 \\
1 \\
\end{array}$ & $\begin{array}{c}49,33 \\
1 \\
\end{array}$ \\
\hline $\begin{array}{l}5345 \\
\text { nort } \\
\text { h \$ } \\
\text { sout } \\
\text { h }\end{array}$ & & & & 9 & $\begin{array}{l}185 \\
.60\end{array}$ & $\begin{array}{c}1,670 . \\
40\end{array}$ & $\begin{array}{c}10 \\
8\end{array}$ & $\begin{array}{l}3 . \\
14\end{array}$ & $\begin{array}{c}339.1 \\
2\end{array}$ & 2 & $\begin{array}{r}168 \\
.92\end{array}$ & $\begin{array}{c}337 . \\
84\end{array}$ & 1 & $\begin{array}{l}2 . \\
63\end{array}$ & 2.63 & 270 & & $\begin{array}{c}1,420.3 \\
6\end{array}$ & 3,768 \\
\hline $\begin{array}{l}5485 \\
\text { nort } \\
\text { h \$ } \\
\text { sout } \\
\text { h }\end{array}$ & & & & 12 & $\begin{array}{c}185 \\
.60\end{array}$ & $\begin{array}{c}2,227 . \\
20\end{array}$ & $\begin{array}{c}14 \\
4\end{array}$ & $\begin{array}{l}3 . \\
14\end{array}$ & $\begin{array}{c}452.1 \\
6\end{array}$ & 2 & $\begin{array}{c}168 \\
.92\end{array}$ & $\begin{array}{c}337 . \\
84\end{array}$ & 2 & $\begin{array}{l}2 . \\
63\end{array}$ & 5.26 & 360 & & $\begin{array}{c}1,893.8 \\
1\end{array}$ & 4,911 \\
\hline $\begin{array}{l}\text { TOT } \\
\text { AL }\end{array}$ & $\begin{array}{c}12 \\
0\end{array}$ & $\begin{array}{l}189 \\
.71\end{array}$ & 22,765 & 74 & $\begin{array}{l}185 \\
.60\end{array}$ & $\begin{array}{c}13,73 \\
4\end{array}$ & $\begin{array}{c}88 \\
1\end{array}$ & $\begin{array}{l}3 . \\
14\end{array}$ & 2,766 & 8 & $\begin{array}{r}168 \\
.92\end{array}$ & $\begin{array}{c}1,35 \\
1\end{array}$ & 21 & $\begin{array}{l}2 . \\
63\end{array}$ & 55 & 2,200 & 13,527 & $\begin{array}{c}15,255 . \\
69\end{array}$ & $\begin{array}{c}69,39 \\
9.77\end{array}$ \\
\hline
\end{tabular}




\subsubsection{Proposed system Schematic}

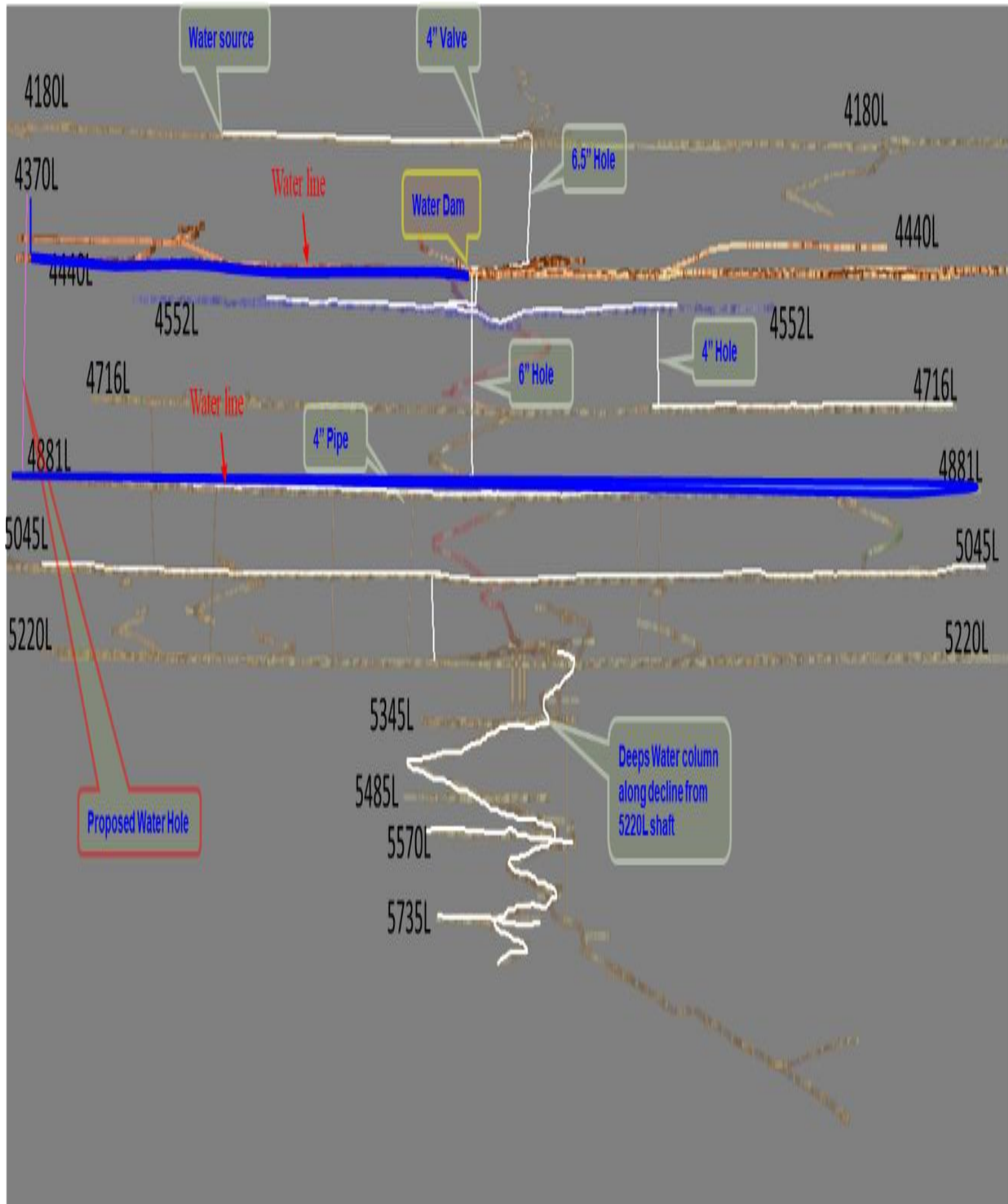

Figure 20: Water service system schematic-4180level to 5814level

Figure 20 depicts water service system with blue lines indicating proposed ring feed into the current system and white lines shows current system.

\subsection{Dewatering}

MSV water management is at the moment one of most challenging factor in both sustainable productivity and production. Current underground operations have intersected major water bearing formations influencing the quality and quantity of water in the mining operations areas and in its surroundings and changes ground conditions, sometimes drastically. Water balance management and large water quantities have lately been one of the main reasons causing tramming ways hitches and exposing to some kind of risk related to the locomotive derailment. This circumstance cause significant effects on the smooth mining operations. See Figure 21. 


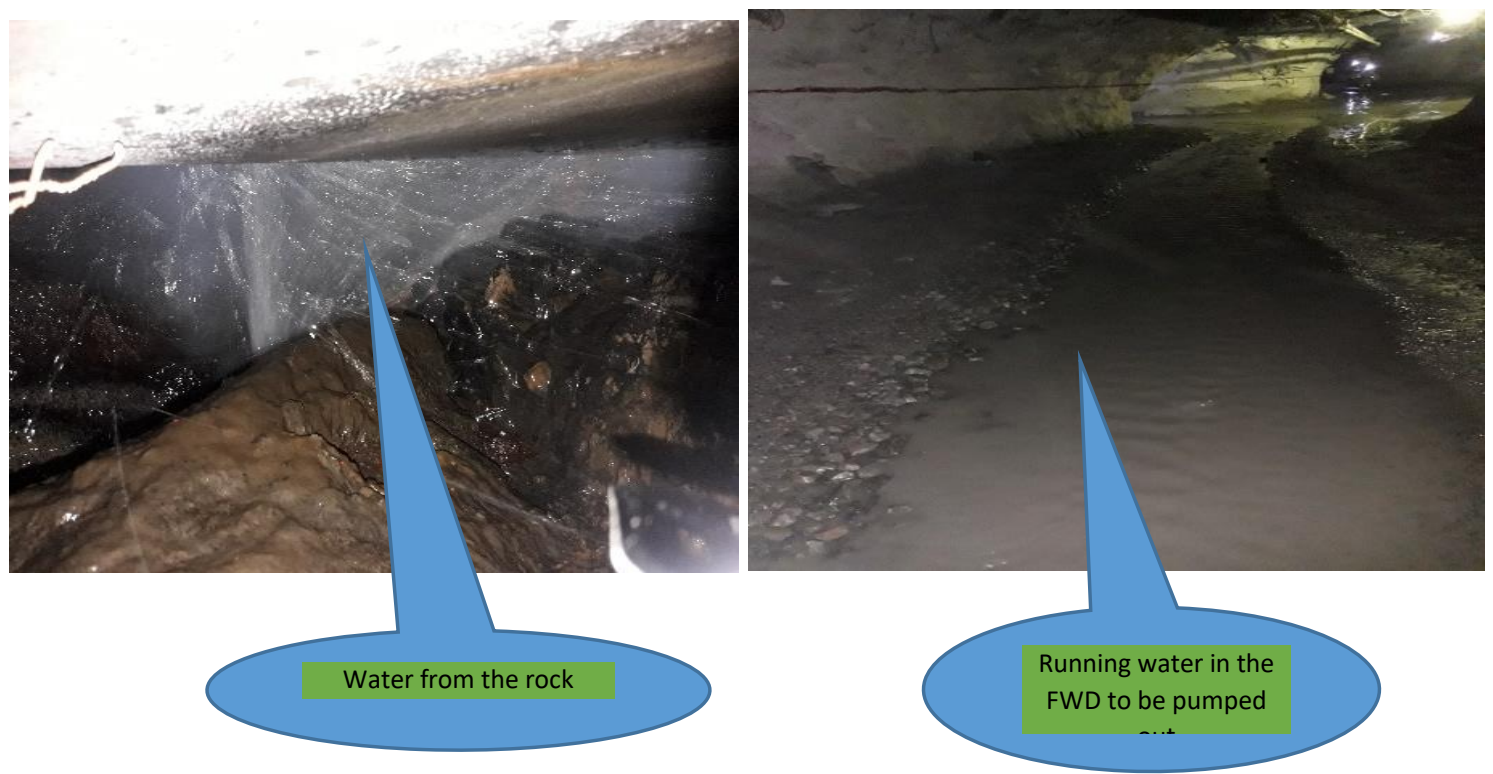

Figure 21: Deeps water source and 5045 level foot wall drive

The pumping of mine water is through the cascade system provided by the main pump chambers on $5360 \mathrm{ft}, 4180 \mathrm{ft}$ and $2930 \mathrm{ft}$ levels. The settlers located on 4440ft level serves as sumps in the upper section and water is pumped by auxiliary pumps to the main stream via 41801 .

Figure 21 shows the upper section which has significant hosing amounts of water, which is channeled through the water drive and verves to the 4440 level settlers, and pumped out to 4140 level. When there is a pump failure at 4440 auxiliary pump chamber, it is diverted in 900 raise via 4440 to 4552 south level down ramp resulting into severe damage of the main ramp and other road ways in the sections. Water is collected at 52201 setters, and pumped out to 41801 . When the 2930 level chamber pumps fail, no water is pumped to surface and finally roots into flooding of the main tramming levels. Consequently, resulting into production stand still.

Generally, water management is a continuous process that needs to be settled and updated throughout the whole mine life cycle, for instance when changes in mining operations also affect the water stability. The lack of comprehensive and practical tools for efficient water management seems to be one of the main causes behind the delinquent.

While word wide all underground mines have introduced water management systems that extraction process results in a lowering of water levels in production areas and adjacent aquifers which may impact upon water bores and natural springs in the surrounding area. The underground water management framework offers a process for assessing, monitoring and making good any impacts on underground water. The key aspects are comprehensive water monitoring program and strategy of projections of potential future water level impacts. This include the immediately de-flooding of affected production and capital development areas which may trigger negatively on mining performance.
The system also involves water monitoring strategies such as (a) Monitoring the extent of the impact on underground water from different levels (b) Monitoring the quantity of water taken or produced (c) Changes in the water level of aquifers (d) Changes in the water quality in aquifers resulting from water level decline. (e) Identify potentially affected springs and assess the connectivity between the spring, and the aquifer assessment and options to prevent or mitigate any impacts. (Punkkinen, 2016).

\subsection{COMPRESSED AIR}

Currently, the mine is facing challenges with supplying compressed air to various sections in both Lower and deeps section. This is mainly due to leakages along the main line which runs in the $1580 \mathrm{~N}$ raise. The introduction of using compressed air at waiting places and in the refugee chambers, has also contributed as the mine goes deep. This has greatly impacted progress on planned drilled reserves resulting into production delays.

Replacement of the broken columns is currently a challenge since there are no service ladders in place. An alternative plan has consequently been developed which will by-pass the $1580 \mathrm{~N}$. The works involves opening the already existing $1250 \mathrm{~N}$ raise as an emergency escape route and passage way for the compressed air columns from $4440 \mathrm{~L}$ to $4552 \mathrm{~L}$. The project is aimed at mitigating the challenges being faced in terms of compressed air supply. In this regard, the column will be re-directed from the current $1580 \mathrm{~N}$ raise which is not equipped with ladders to $1250 \mathrm{~N}$ raise. Also the size of the column will increase from 6 inch to 8 inch in order to supply the expanding sections in both Lower and deeps levels.

Two scenario where considered for analysis to ascertain the importance of compressed air on cubex drilling,

\subsubsection{SCENARIO 1}

First scenario was on Cubex 13 which dependably on mine air from the compressor house. It took three months to 
complete drilling 2500 meters in the chamber because of constant low mine air.

\section{3 .2 SCENARIO 2}

Secondly was on Cubex 18 on which all connections where reliably on standalone compressors and it assisted efficiently drilling of 2500meters in six weeks without the machine tripping on low mine air. Henceforth, all cubex machines being procured will have compressor built-in, hence, the heat load can then be placed on the return side thereby improving working conditions.

In general, in all underground mines globally, compressed air is a very important source of power for drilling holes for blasting, agitation in settlers, live saving in refuge chambers and breathable source of air that can be used in hazardous mining environments. Compressed air can also be used for eliminating unwanted particles from filters and other spaces amid the dirt and dust of the mining operation. It is a clean source of air and can be used effectively without the need for additional cleaning materials. This assists to extend the durability of critical mining equipment and reduce any downtime needed for maintenance.

\subsection{CONCLUSIONS AND RECOMMENDATIONS}

Mindola Subvertical mine production is affected by several factors. These hiccups provide challenges in sustainable ore availability and overall production performance. The study shaded more lights on the parameters affecting the productivity at MSV mine. A lot of effort has gone into incorporating improvements and additions that will truly add value in to various mining unit processes throughout the mining life and helping MSV gain the very best results in production. The global mine productivity issues at MSV indicated that reducing various supervisory challenges in mining unit and auxiliary operations together with progress in equipment technology would result in improved productivity and production as in comparisons to the global mine productivity. Efficient strategic and tactical management plans can also increase productivity of both men and machinery.

\section{REFERENCES}

[1] AcQuire technology. (2018).Geoscientific Information Management

[2] AutoCAD.

(2013).Introduction-to-Autocadhttps://cadsetterout.com/reviews, accessed date 20/02/2020.

[3] Bwalya. V. (2019). Mine Design Criteria "Nkana North Mine" Business Plan.

[4] Cleverism. (2018).Cognitive development. https://www.cleverism.com, accessed date, 23/02/2020.

[5] Carlson software (2019). Ground deformations. https://www.carlsonsw.com/products/officesoftware/carlson, accessed, date 02/01/2020.

[6] Caterpillar. (2019). Loaders. https://www.epiroc.com/enjo/products/drill-rigs/surface-blasthole-drill-rigs/pv-351.

[7] Caterpillar. (2019).Third quarter report results.

[8] Caledonia mining. (2020). Operating assets. https://www.caledoniamining.com/operations/blanket-goldmineoftware.accessed, 14/09/2019.

[9] Cleverism. (2018).Cognitive development. https://www.cleverism.com, accessed date, 23/02/2020.

[10] Datamine. (2020). Mine management software. http://centricminingsystems.com, accessed date, 23/02/2020.

[11] Daunia Coal Mine, Queensland. (2019). Mining technology. https://www.mining-technology.com/projects/daunia-coal-minequeensland-australia, accessed date, 02/01/2020
[12] Demand solutions. (2020). Supply chain software 24/7/company. https://www.google.com/search.

[13] Epiroc. (2017). Mining equipment. https://www.epiroc. Com/enbf/customer-stories, accessed date, 23/012020.

[14] Fine software. (2020). Geotechnical software. https://www.finesoftware.eu/geotechnical-software. Accessed date, $09 / 12 / 20$

[15] Fixsoftware (2019) Planned-maintenance. https://www.fiixsoftware.com/planned-maintenance.

[16] Geovia surpac. (2019).The world's most popular geology and mine planning software

[17] Greenfield. P. (2007). International Water Centre URS

[18] Goel, S. C. (1986). Implementation of blast hole open stoping using a down-the-hole machine at Nkana. Internal report no. RM56, 04/86, Mineral Resources Development Limited. (https://www.3ds.com/products-services/geovia/products/surpac/) 6 Feb 2020 07:55:26 GMT

[19] Granseberg, D.D. (2015).Major equipment life cycle cost analysis, research project report, Institute for Transportation Iowa State University.

[20] Geovia. (2020). https://www.g2.com/products/geoviasurpac/reviews, accessed date, 13/02/2020.

[21] Gefasystem. (2020). Aarctic-ventcontrol).https://www.gefasystem.se/arctic-vent-control.

[22] Goel, S. C. (1986). Implementation of blast hole open stoping using a down-the-hole machine at Nkana. Internal report no. RM56, 04/86, Mineral Resources Development Limited. (https://www.3ds.com/products-services/geovia/products/surpac/) 6 Feb 2020 07:55:26 GMT

[23] HPE RIGS. (2020). Underground Drilling Rigs Overview, https://www.hpesa.com/product-category/mining solutions/underground-drilling-rigs, Accessed date, 15/030/2020.

[24] Life cycle engineering (2020). Maintenance-Management-Skills.https://www.lce.com/Maintenance-Management-Skills511.html, accesed date 25/11/2019.

[25] MacEwan University. (2020). Management and supervision. https://aboutleaders.com/management and supervision vs leadership. Accessed date, 12/20/2020.

[26] Punkkinen. (2016). Guidelines for mine water management

[27] Life cycle engineering (2020). Maintenance-Management-Skillshttps://www.lce.com/Maintenance-Management-Skills511.html, accesed date 25/11/2019.

[28] Lappalainen. E. (1996). Description of the geology of peatiand areas for $\mathrm{t} h$ e excursion of the symposium.

[29] Micromine. (2020).3D mine design https://www.micromine.com/mining grade control, accessed date, $12 / 20 / 2020$

[30] MacEwan University. (2020). Management and supervision. https://aboutleaders.com/management and supervision vs leadership. Accessed date, 12/20/2020.

[31] Salunkhe. R.T. (2019). Inventory control, ISSN: 2278-1684, PP: 43-47.

[32] Sandvik. 2018. Mining rock technology. Mining rock technology.https://www.rocktechnology.sandvik/en/products/und erground-drill-rigs-and-bolters/in-the-hole-longhole-drills.acessed date, $12 / 20 / 2020$.

[33] VentSim. (2019). Rich visual 3D mine ventilation simulation.

[34] Whittle. D. (2018). Factors that influence mine design and project value.

[35] Wikipedia. (2020). Fatigue management in mining - Time to wake up and act, https://www.aviation-qualityservices.com/training/frm-training, Accessed date, 15/03/2020.

[36] Whittle, D. (2018). Factors that influence mine design and project value.

[37] Wikipedia. (2019). Dump trucks. https://en.wikipedia.org/wiki/Dump truck. accessed date, $02 / 01 / 2019$

[38] Wikipedia. (2020).

Productivity https://en.wikipedia.org/wiki/Productivity . accessed date, $15 / 01 / 2019$.

[39] Wiles. T. (2011). Map3D, Rock Mechanics Award of the Rock Engineering. 